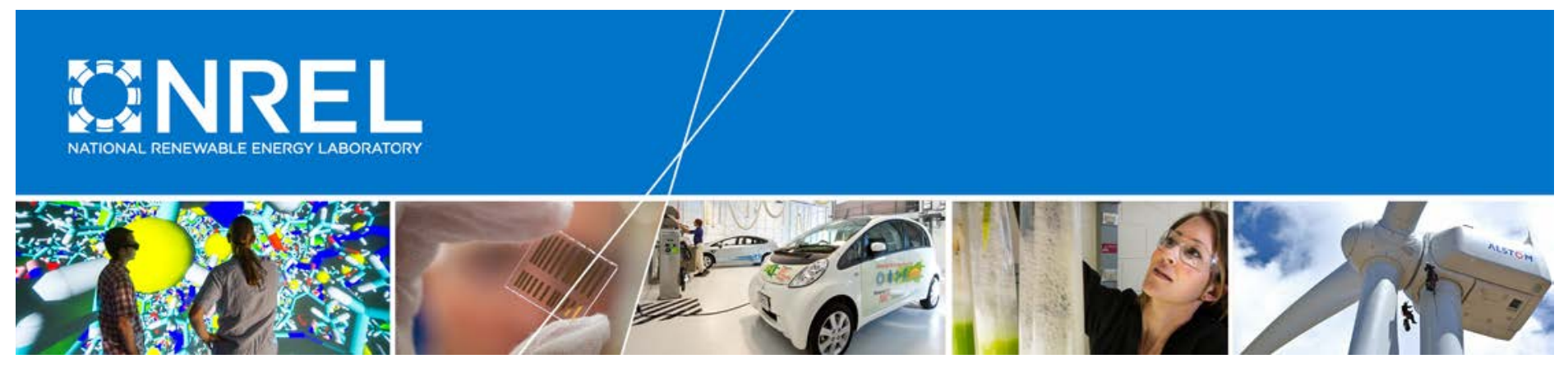

\title{
Negotiating Terms and \\ Conditions: An Overview of the \\ Federal Energy Regulatory \\ Commission Hydropower \\ Settlement Agreement Process
}

Aaron Levine, Taylor Curtis, and Laura Shields

National Renewable Energy Laboratory

NREL is a national laboratory of the U.S. Department of Energy

Office of Energy Efficiency \& Renewable Energy

Operated by the Alliance for Sustainable Energy, LLC

This report is available at no cost from the National Renewable Energy Laboratory (NREL) at www.nrel.gov/publications.

Technical Report

NREL/TP-6A20-71093

June 2018

Contract No. DE-AC36-08GO28308 


\title{
Negotiating Terms and Conditions: An Overview of the Federal Energy Regulatory Commission Hydropower Settlement Agreement Process
}

\author{
Aaron Levine, Taylor Curtis, \\ and Laura Shields \\ National Renewable Energy Laboratory
}

\section{Suggested Citation}

Levine, Aaron, Taylor Curtis, and Laura Shields. 2018. Negotiating Terms and Conditions: An Overview of the Federal Energy Regulatory Commission Hydropower Settlement Agreement Process. Golden, CO: National Renewable Energy Laboratory. NREL/TP-6A20-71093. https://www.nrel.gov/docs/fy180sti/71093.pdf.

NREL is a national laboratory of the U.S. Department of Energy

Office of Energy Efficiency \& Renewable Energy

Operated by the Alliance for Sustainable Energy, LLC

This report is available at no cost from the National Renewable Energy Laboratory (NREL) at www.nrel.gov/publications.

National Renewable Energy Laboratory 15013 Denver West Parkway Golden, CO 80401

303-275-3000 • www.nrel.gov

\section{Technical Report}

NREL/TP-6A20-71093

June 2018

Contract No. DE-AC36-08GO28308 


\section{NOTICE}

This report was prepared as an account of work sponsored by an agency of the United States government. Neither the United States government nor any agency thereof, nor any of their employees, makes any warranty, express or implied, or assumes any legal liability or responsibility for the accuracy, completeness, or usefulness of any information, apparatus, product, or process disclosed, or represents that its use would not infringe privately owned rights. Reference herein to any specific commercial product, process, or service by trade name, trademark, manufacturer, or otherwise does not necessarily constitute or imply its endorsement, recommendation, or favoring by the United States government or any agency thereof. The views and opinions of authors expressed herein do not necessarily state or reflect those of the United States government or any agency thereof.

This report is available at no cost from the National Renewable Energy Laboratory (NREL) at www.nrel.gov/publications.

Available electronically at SciTech Connect http:/www.osti.gov/scitech

Available for a processing fee to U.S. Department of Energy and its contractors, in paper, from:

U.S. Department of Energy

Office of Scientific and Technical Information

P.O. Box 62

Oak Ridge, TN 37831-0062

OSTI http://www.osti.gov

Phone: 865.576.8401

Fax: 865.576.5728

Email: reports@osti.gov

Available for sale to the public, in paper, from:

U.S. Department of Commerce

National Technical Information Service

5301 Shawnee Road

Alexandria, VA 22312

NTIS http://www.ntis.gov

Phone: 800.553 .6847 or 703.605 .6000

Fax: 703.605.6900

Email: orders@ntis.gov 


\section{Acknowledgments}

The authors gratefully acknowledge the U.S. Department of Energy Office of Energy Efficiency and Renewable Energy Water Power Technologies Office for its funding support. We thank Kathleen (Katie) McLaughlin for her research assistance. We also thank the following reviewers for their time and expertise: Corey Vezina and Tim Welch, U.S. Department of Energy; Elizabeth Molloy, Federal Energy Regulatory Commission; David Zayas, National Hydropower Association; Jaquelin Cochran, Dave Mooney, and Sheri Anstedt (editor), National Renewable Energy Laboratory. 


\section{Executive Summary}

The process for obtaining, transferring, or surrendering a Federal Energy Regulatory Commission (FERC) hydropower license or exemption from licensing can be a series of complex negotiations. In many instances, the process may include stakeholders with different and/or competing perspectives or objectives related to the original license, new license (i.e., relicense), transfer of a license, or surrender of a license. Divergent perspectives and objectives can lead to disputes among project participants, which may impact the development of FERC license terms and conditions. One mechanism to resolve disputes between project participants involving a FERC authorization is informal and formal settlement agreement conferences, which often result in settlement agreements addressing the disputed issues.

This report provides hydropower stakeholders with a better understanding of the FERC settlement agreement process, including information on:

- How to initiate a settlement agreement

- The procedural steps associated with the settlement agreement process

- The legal standards the Commission must adhere to when determining whether settlement agreement provisions can become lawful and enforceable terms or conditions of a FERC authorization

- Examples of settlement agreement provisions included as license terms and conditions or in off-license agreements from a collection of settlement agreements and Commission orders.

This report provides specific information related to various types of settlement agreement and off-license provisions, including dispute resolution, adaptive management, recreational enhancements, site access, cost sharing, cost caps, mitigation and enhancement funds, license term length, water quality, flow level and management, species and habitat protection, preservation of historic properties, and damages. 


\section{Table of Contents}

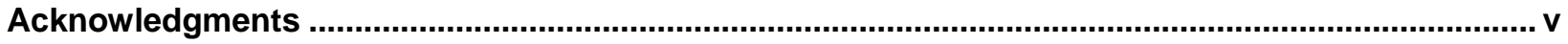

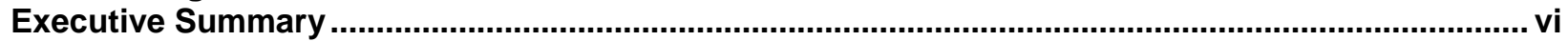

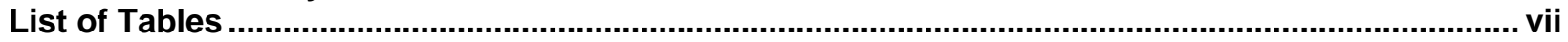

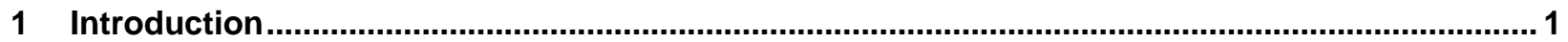

2 Settlement Agreement Process and Legal Standard .............................................................. 3

2.1 FERC Settlement Agreement Procedures ........................................................................ 3

2.2 Informal and Formal Settlement Conferences...................................................................... 3

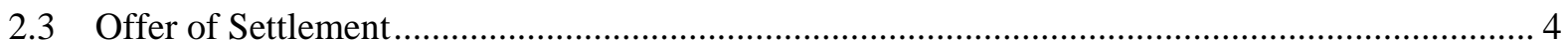

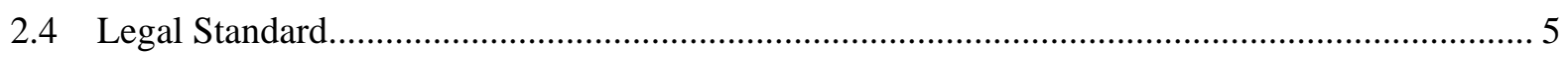

3 Common Settlement Agreement License Terms and Conditions and Off-License Terms......... 22

3.1 Common Settlement Agreement License Terms and Conditions ............................................ 22

3.2 Common Off-License Settlement Agreement Terms .......................................................... 26

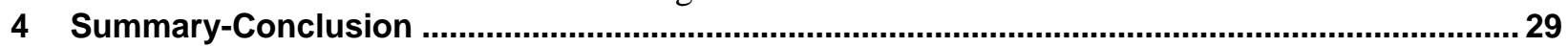

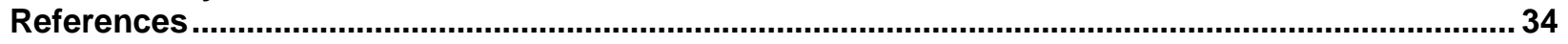

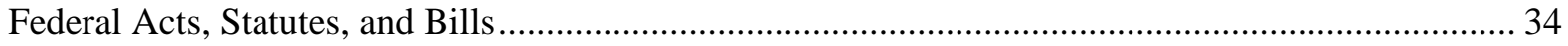

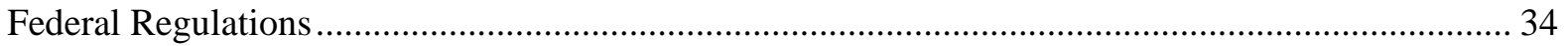

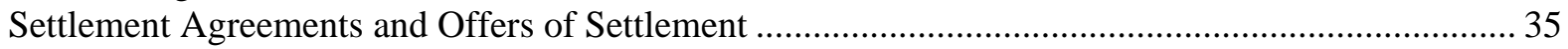

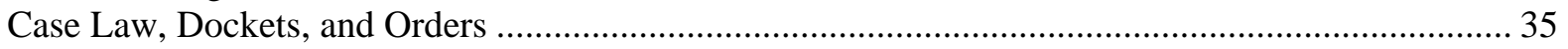

\section{List of Tables}

Table 1. Summary of the Enforceability of Proposed Settlement Agreement License Terms and Conditions

Table 2. Types of Settlement Agreement Provisions That May Be Included As License Terms and

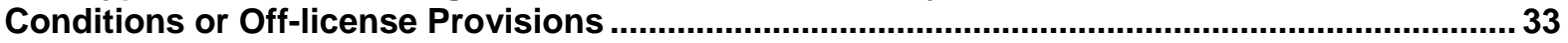




\section{Introduction}

The process for obtaining, transferring, or surrendering a Federal Energy Regulatory Commission (herein FERC or the Commission) hydropower license or exemption from licensing (herein license) can be a series of complex negotiations. In many instances, the process may include stakeholders with different and/or competing perspectives or objectives related to the original license, new license (i.e., relicense), transfer of a license, or surrender of a license (herein FERC authorization or authorization).

Under the Federal Power Act (FPA) (16 U.S.C. $\S \S 791$ et seq.), the Commission has authority to license ${ }^{1}$ certain nonfederal hydropower projects. Generally, a FERC license is required to construct, operate, and maintain nonfederal hydropower projects that:

- Are located on navigable waters of the United States

- Occupy public lands or reservations of the United States

- Utilize surplus water or water power from a U.S. government dam

- Are located on a stream over which Congress has Commerce Clause jurisdiction, where project construction or expansion occurred on or after August 26, 1935, and the project affects the interests of interstate or foreign commerce.

16 U.S.C. § 817

Divergent perspectives and/or objectives can lead to disputes among project participants, which may impact FERC license terms and conditions or create other issues related to construction, operation, or surrender of the hydropower project. These participants may include, but are not limited to, project licensees and associated contractors; federal and state land management agencies; federal and state resource agencies (e.g., environmental/water quality/biological); local governments; American Indian Tribes; nongovernmental organizations; and other community stakeholders.

One mechanism to help resolve disputes involving a FERC authorization is informal and formal settlement agreement conferences, which can establish the position of the stakeholders and their respective interests in the outcome of the proceeding. Settlement agreement conferences often result in an offer of settlement, which any participant to a proceeding may submit to the Commission at any time before the Commission issues a final decision (i.e., final order) for the license (18 C.F.R. § 385.602[b]). ${ }^{2}$ Settlement agreements may include all participants to the proceeding and address all disputed issues or may include a subset of participants and narrowly focus on a specific issue(s), which in some cases results in multiple settlement agreements for a single FERC authorization. Following submission of the settlement agreement, the Commission reviews the settlement agreement(s) (and comments thereto) to determine whether the agreement

\footnotetext{
${ }^{1}$ In addition to issuing preliminary permits (16 U.S.C. § 800) and authorizing license renewal (16 U.S.C. § 808), transfer (16 U.S.C. § 801), and surrender (16 U.S.C. § 799).

2 “In the context of hydropower license proceedings, a 'settlement' that is not supported by the licensee or any of the resource agencies with jurisdiction in the matter is not truly a settlement, but is rather simply a recitation of the filer’s position in the case.” Duke Energy Carolinas, LLC, 120 FERC ๆ 61,054, citing Erie Boulevard Hydropower, L.P., 117 FERC ๆ 61,189 at P 63 (2006).
} 
is contested and to what extent the settlement agreement provisions may be incorporated into the license and enforced by the Commission.

To provide hydropower stakeholders with a better understanding of the FERC settlement agreement process, this report details:

- How to initiate a settlement agreement

- The procedural steps associated with the settlement agreement process

- The legal standards the Commission must adhere to when determining whether settlement agreement provisions can become lawful and enforceable terms or conditions of a FERC authorization

- Examples of settlement agreement provisions included as license terms and conditions or in off-license agreements from a collection of settlement agreements and Commission orders. 


\section{Settlement Agreement Process and Legal Standard}

This section discusses how to initiate a FERC settlement agreement, the procedural steps associated with the settlement agreement process, and the legal standards that the Commission must adhere to when determining whether a settlement agreement provision can become a lawful and enforceable term or condition of a FERC authorization.

\subsection{FERC Settlement Agreement Procedures}

Settlement agreements are an accepted method to resolve disputes for any proceeding before the Commission (18 C.F.R. $\S 385.601[a]$ ). Any hydropower project seeking a FERC authorization may enter into a settlement agreement to resolve a disputed issue. The Commission encourages parties to enter into settlement agreements to resolve disputes (FERC 2006).

The regulatory and review processes for a settlement agreement are the same for any proceeding before the Commission. For instance, settlement agreement regulatory and review processes for the transfer of an authorization or surrender of an authorization are the same as for an original license, new license (i.e., relicense), or an exemption from licensing.

\subsection{Informal and Formal Settlement Conferences}

To initiate a settlement agreement, an informal ${ }^{3}$ or formal settlement conference is often convened to ascertain the positions of the parties and their respective interests in the outcome of the proceeding (Consumers Power Company, 68 FERC 9 61,077 [1994]; Walker 1986). At the settlement conference, issues are identified for resolution and trial procedures are established (Panhandle E. Pipe Line Co., 29 FERC I 61,281 [1984]).

Any participant ${ }^{4}$ or party, ${ }^{5}$ including Commission staff, may convene an informal settlement conference. Informal conferences are not subject to the notice and participation requirements set forth in 18 C.F.R. $\S 385.601$ (Walker 1986). Formal conferences, however, must follow the notice and participation requirements laid out in Rule 601 and may only be convened by the Commission (18 C.F.R. § 385.601). The Commission “...may, upon motion or otherwise, convene a formal conference of participants in a settlement agreement proceeding at any time for any purpose related to...the submission and consideration of offers of settlement...” (18 C.F.R. $\S 385.601)$.

The Commission favors settlement agreement conferences because they enable “...the parties to discuss openly their positions and concerns on the contested issues in the case” (Centel Corp., Western Power Div., 27 FERC 9 63,071 [1984]). The Commission encourages all parties to a

\footnotetext{
${ }^{3}$ See, e.g., Consumer Power Company, 68 FERC 91 61,077 (1994) (p. 20) (“Settlement procedures provide the opportunity to eliminate the need for more lengthy proceedings, either formal or informal, when the parties reach an agreement on the issues and if the agreement is compatible with the public interest.”) (emphasis added); Clifton Power Corp., FERC Docket No. P-4632-013 (1993) ("The Chief Judge finds that an informal settlement conference in this case...is in the public interest and may result in a more expeditious final determination of this case...”) (emphasis added).

4 "Participant" means "any party; or any employee of the Commission assigned to present the position of the Commission staff in a proceeding before the Commission” (18 C.F.R. § 385.102(b)).

5 "Party" means, in part, "any respondent to a proceeding; or any person whose intervention in a proceeding is effective under 18 C.F.R. § 385.214” (18 C.F.R. § 385.102(c)).
} 
proceeding to participate in the settlement conference to consider and accommodate all divergent views and interests (Energy Terminal Serv. Corp., 20 FERC 1 61,053 [1982]). Moreover, FERC regulations specifically state that failure of a party to attend a formal settlement conference will constitute a “...waiver of all objections to any order or ruling arising out of, or any agreement reached at the conference” (18 C.F.R. § 385.601[b][3]).

\subsection{Offer of Settlement}

An offer of settlement is often a result of an informal or formal conference (Walker 1986). Any participant or party to a proceeding may submit an offer of settlement to the Commission at any time before the Commission issues a final decision (i.e., final order) (18 C.F.R. § 385.602[b]). ${ }^{6}$ However, submitting an offer of settlement before or during the early stages of prefiling and National Environmental Policy Act (NEPA) review can prevent conflicts between the licensee/exemptee (herein licensee), ${ }^{7}$ land management agencies, resource agencies, and other interested parties that often lead to delays in the FERC authorization process (Roos-Collins, 2015). For example, an offer of settlement can reduce the frequency or severity of disputes and adverse comments regarding the study plan (e.g., required studies, scope of studies, study methodologies, data collection, and additional study requests) (Work Group on the Coordination of Federal Mandates 2000).

An offer of settlement must include an explanatory statement that shows how the settlement is the proper basis for the proceeding decision (18 C.F.R. § 385.602[c]). An offer of settlement does not have to address all disputed issues, nor require all parties to the proceeding to sign the offer of settlement. ${ }^{8} 9$

The participant offering settlement must serve a copy of the offer on every party to the proceeding and must expressly notify all participants, and any person required by the Commission's rules, when comments regarding the offer are due (18 C.F.R. § 385.602[d]). Parties and participants, as well as nonparties, ${ }^{10}$ may file comments no later than 20 days after the offer of settlement is filed (18 C.F.R. § 385.602[f][1]-[2]). Reply comments may be filed with the Commission no later than 30 days after the offer is filed (18 C.F.R. § 385.602[f][2]). In practice, reply comments are often filed no later than 10 days after initial comments are filed

\footnotetext{
6 "In the context of hydropower license proceedings, a 'settlement' that is not supported by the licensee or any of the resource agencies with jurisdiction in the matter is not truly a settlement, but is rather simply a recitation of the filer’s position in the case.” Duke Energy Carolinas, LLC, 120 FERC 9 61,054, citing Erie Boulevard Hydropower, L.P., 117 FERC $\$$ 61,189 at P 63 (2006).

7 The report hereinafter will use the word "licensee" to include licensees and exemptees, except for individual case study examples.

${ }^{8}$ See, e.g., Duke Energy Progress, Inc., 153 FERC 9 61,056 (2015) (pdf. 4) (“Although American Rivers and Rockingham participated in the negotiations, they declined to sign the agreement.”); Symbiotics, 124 FERC $\mathbb{9}$ 62,059 (2008) (pdf. 4) ("The Snake River Cutthroats originally participated in the settlement negotiations. The group, however did not sign the final agreement because... [the group] did not agree with the size of the turbine fish screens and the mitigation...”)

${ }^{9}$ See, e.g., Upper Peninsula Power Company, 104 FERC $\$$ 62,135 (2003) (pdf. 1) (“Upper Peninsula Power Company filed a settlement agreement with the Commission on July 11, 2000. The Agreement proposed measures to resolve most of the relicensing issues that pertain to the operation of the project.”)

${ }^{10}$ El Paso Natural Gas Co., 24 FERC I 63,008 at 65,022 (1983) (finding that non-parties are entitled to file comments on the offer of settlement).
} 
with the Commission (Roos-Collins and Gantenbein 2015). Failure to file comments constitutes a waiver of all objections to the offer of settlement (18 C.F.R. § 385.602[f][2]).

The Commission considers all comments before making a determination on a proposed offer of settlement. The Commission or the presiding officer ${ }^{11}$ must first review the comments filed on the settlement to determine whether the settlement agreement is contested in whole or in part (18 C.F.R. § 385. 602[g]). Comments requesting clarification or modification of a proposed settlement agreement do not render the proposal contested (Consolidated Gas Supply Corp., 27 FERC I 61,426 [1984]). Contested settlement agreements must comply with the regulations set forth in 18 C.F.R. $\S 385.602[h]$.

\subsubsection{Contested and Uncontested Settlement Agreements}

The Commission may approve a contested settlement agreement if the record contains substantial evidence upon which a reasoned decision can be based, or if the Commission finds that no genuine ${ }^{12}$ issue of material ${ }^{13}$ fact exists (18 C.F.R. $\S 385.602[h][1][i]$, Michigan Wis. Pipe Line Co., 20 FERC 9 61,423 [1982]). The Commission evaluates the underlying facts of the settlement agreement to determine whether there are any issues of material fact (Pennsylvania Gas \& Water Co. v. FPC, 463 F.2d 1242 [D.C. Cir. 1972], Trunkline Gas Co., 22 FERC 1 63,114 [1983]). The Commission also examines the interests of the parties who object to the settlement in determining whether there are any contested issues of material fact. The Commission has held that the objections of a party with no present or immediate interest in a settlement agreement will not render the settlement contested (Trans-Alaska Pipeline Sys., 35 FERC ๆ 61,425 [1983]).

Ultimately, if contested issues of material fact exist, the Commission may still approve a contested offer of settlement if the record contains substantial evidence on which the Commission can reach a reasoned decision concluding that the proposal will establish "just and reasonable results” (18 C.F.R. § 385.602[h], Mobil Oil Corp., v. Fed. Power Comm’n, 417 U.S. 283 [1974]). The Commission may approve an uncontested settlement agreement if the proposal is fair and reasonable and in the public interest (18 C.F.R. § 385.602[g][3]; Placid Oil Co. v. FPC, 483 F.2d 880 [5 ${ }^{\text {th }}$ Cir. 1973]). The Commission may modify, approve, or disapprove a settlement agreement, in whole or in part, in the final decision (16 U.S.C. §§ 797[e], 799, 801, 803[a][1], 808[a][1], FERC 2006).

\subsection{Legal Standard}

For a settlement provision to become a term or condition of a FERC authorization, the provision must: (1) meet the public interest Comprehensive Development and Equal Consideration Standard, and (2) the Commission must have jurisdiction to enforce the provision.

\footnotetext{
1118 C.F.R. § 385.102(e) (defining “presiding officer” in part to mean “...one or more Members of the Commission, or any administrative law judge, designated to preside at such hearing, or, if no Commissioner or administrative law judge designated, the Chief Administrative Law Judge...”).

${ }^{12}$ A dispute of material fact is genuine if the evidence could lead "a reasonable [decision-maker] to return a [decision] in favor of the nonmoving party” (Anderson v. Liberty Lobby, Inc. 477 U.S. 242, 250 (1986)).

${ }^{13}$ A fact is material if it "might affect the outcome of the [proceeding] under the governing law" (Anderson $v$. Liberty Lobby, Inc. 477 U.S. 242, 248 (1986)).
} 


\subsubsection{Public Interest Comprehensive Development and Equal Consideration Standard}

Section 10(a)(1) of the FPA requires the Commission to determine whether any licensed/exempted project, and thereby any term or condition of the license is in the interest of the public. When making a public interest determination, the Commission must provide equal consideration ${ }^{14}$ to development and nondevelopment values, including:

- Improvement or development of a waterway for the use or benefit of interstate or foreign commerce

- Improvement and utilization of water power development

- Adequate protection, mitigation, and enhancement of fish and wildlife (including related spawning grounds and habitat)

- Beneficial public uses, such as irrigation, flood control, water supply, and recreation

- Energy conservation

- Preservation of other aspects of environmental quality.

(16 U.S.C. § 803(a)(1); 16 U.S.C. § 797(e))

\subsubsection{Project Purpose and Project Effects}

To make a public interest determination, the Commission must determine to what extent the proposed license term or condition relates to the project purpose and project effects by reviewing the facts presented on a case-by-case basis (FERC 2006). The "project purpose" constitutes the requirements of Section 10(a)(1) of the FPA, as discussed in Section 2.4.1 (FERC 2006). The "project effects" are the direct, ${ }^{15}$ indirect, ${ }^{16}$ and cumulative ${ }^{17}$ impacts of the project on the surrounding environment and resources (18 C.F.R. § 5.9[b][5]; FERC 2012).

The Commission can more easily determine that a proposed license term or condition is in the best interest of the public when the settlement provision calls for clear and specific measures supported by a factual record. The factual record should provide substantial evidence ${ }^{18}$ to support the proposed term or condition and demonstrate how the term or condition is related to the project purpose and project effects (FERC 2006).

\footnotetext{
${ }^{14}$ FERC has interpreted “equal consideration” to mean all nondevelopment and development values must be given the same level of reflection and thorough evaluation (FERC 2004).

1540 C.F.R. \$1508.8(a) (defining “direct effects” as those effects that occur in the same place and at the same time and are a direct result of the proposed action).

1640 C.F.R. \$1508.8(b) (defining “indirect effects” as those effects that are caused by the action and are later in time or farther removed in distance but are still reasonably foreseeable).

1740 C.F.R. $\$ 1508.7$ (defining "cumulative impact” as the impact on the environment that results from the incremental impact of the action when added to other past, present, and reasonably foreseeable future actions regardless of what agency or person undertakes such actions. Cumulative impacts can result from individually minor but collective significant actions taking place over a period of time).

${ }^{18}$ FERC settlement decisions, like all FPA-related decisions, must be supported by substantial evidence (16 U.S.C. $\S 8251)$. Substantial evidence constitutes “...evidence that a reasonable mind might accept as adequate to support a conclusion” (Universal Camera Corp., v. NLRB, 340 U.S. 474, 477 [(1951).
} 


\section{Example: Approved Settlement Provision-Measures Sufficiently Related to the Project Purpose and Project Effects}

In Virginia Electric Power Company, 111 FERC 9 61,241 (2005), the Commission approved a settlement agreement provision, on rehearing, requiring a number of protection, mitigation, and enhancement measures for the relicense of a 329-megawatt (MW) hydropower project on the Roanoke River in North Carolina. The Commission reasoned that the proposed measures called for specific actions with clear effects and that those measures were sufficiently related to the project purpose and project effects. The Commission stated that it is much “...easier to conclude that a proposed measure is in the public interest if it is specific and calls for actions located within the vicinity of the project” (Virginia Electric Power Company, 111 FERC I 61,241 [2005]).

\subsubsection{Project Boundary}

To demonstrate that a proposed settlement provision is related to the project purpose and project effects, the provision should include specific measures, and those measures should call for actions within the project boundary (FERC 2006). Project boundaries are established to delineate those lands, waters, works, and facilities necessary for the “...operation and maintenance of the project and for other project purposes...” or to “....ameliorate a project effect...” (FERC 2006; Union Electric Co., 118 FERC \ 62,247 [2007]; Duke Energy Progress, Inc.; 151 FERC 962,004 [2015]). "Existing residential, commercial, or other structures may be included in the boundary only to the extent that underlying lands are needed for project purposes (e.g., for flowage, public recreation, shoreline control, or environmental resources)” (18 C.F.R. § 4.41[h][2]; FERC 2006).

Project boundaries make it easier for the Commission, licensee, and other interested parties to understand the geographic scope of the project and the potential project effects (FERC 2006). The inclusion of lands, waters, works, and facilities within a project boundary also serves the function of indicating that the land and all resources on that land are used in some manner for the project purpose or to improve a project effect (FERC 2015; Duke Energy Progress, Inc.; 151 FERC 9 62,004 [2015]). 


\section{Example: Rejected Settlement Provision-Measures Outside of the Project Boundary}

In Northern States Power Co., 111 FERC 9 62,212 (2005), the Commission rejected a settlement agreement provision regarding recreational enhancement measures for the relicense of a 5-MW hydropower project on the Red Cedar River in Wisconsin. The parties to the agreement proposed that the licensee: (1) cooperate with the City of Menomonie in developing a bike trail spur across the licensee's property that would connect the two bike trails located over a mile downstream of the project, (2) replace concrete boat launch pads at a boat landing about a mile downstream of the project, (3) provide funding to the City of Menomonie for the installation of two barrier-free fishing stations about a mile downstream of the project, and (4) provide any outfitter the opportunity to maintain a take-out about four miles downstream from the project. The Commission reasoned that the measures were outside the project boundary and that it was "unclear how the measures address access to project lands or waters..." (Northern States Power Co., 111 FERC ๆ 62,212 [2005]).

\section{Acquiring Property Rights}

All the lands, waters, and facilities needed to carry out the project purpose or improve a project effect should be within the project boundary. The licensee must acquire and retain the rights necessary or appropriate to carry out the project purpose (18 C.F.R. $\S \S 4.41 ; 4.92$ [d]). Standard license Article 5 requires the licensee to acquire title to use all lands necessary or appropriate for the construction, maintenance, and operation of the project. ${ }^{19}$ The licensee can obtain property rights through easement, fee title, leases, and other types of conveyances (18 C.F.R. $§ 4.41[\mathrm{~h}]$; FERC 2015). The inclusion of lands within a project boundary does not create or alter property rights, nor does the conveyance of a property right change a project boundary ${ }^{20}$ (FERC 2015; FERC 2006).

\section{Example: Violation of License Term--Failure to Acquire Property Rights}

In Boyce Hydro Power, LLC., 149 FERC 9 62,027 (2014), the Commission reviewed updated Exhibit G drawings (i.e., project boundary drawings) for the relicense of a 3.3-MW hydropower project on the Tittabawesee and Tobacco Rivers in Michigan. The Commission held that the licensee was in "...violation of the license for failure to maintain/acquire rights to use all lands in the project boundary for project purposes as required by standard Article 5.” The Commission reasoned that the Exhibit G drawings did not clearly show that the licensee had all the necessary property rights within the project boundary, including flowage rights....and property rights for areas of the reservoir adjacent to a nearby subdivision..." (Boyce Hydro Power, LLC., 149 FERC \ 62,027 [2014]).

\section{Redefining the Project Boundary}

The Commission may redefine the project boundary to include additional lands or waters or to remove lands or waters from the project boundary if necessary to align with the project purpose

\footnotetext{
19 “ $[\mathrm{t}]$ he licensee, within five years from the date of the issuance of the license, shall acquire title in fee or the right to use in perpetuity all lands, other than lands of the United States, necessary or appropriate for the construction, maintenance, and operation of the project” (Federal Energy Regulatory Commission, Terms and Conditions of License for Constructed Major Project Affecting Navigable Waters and Lands of the United States (Form L-5 (Oct. 1975)).

${ }^{20}$ See, e.g., Niagara Mohawk Power Corp., 77 FERC $\$$ 61,306 (1996) (property rights are governed by state law, whereas project boundaries are determined by the Commission).
} 
(e.g., for flowage, public recreation, shoreline control, or environmental resources) or improve a project effect. Generally, to add land to or remove land from a project boundary, a licensee must revise the description of the project lands and the exhibits that show the project works and project boundaries. After FERC has issued a new license (i.e., relicense) or an original license, the licensee must file a non-capacity license amendment to revise the project boundary (18 C.F.R. §§ 4.200 - 4.201, Union Electric Co., 118 FERC I 62,247 [2007]).

\section{Adding Land to the Project Boundary}

The Commission may require control of additional lands and direct the licensee to obtain additional property rights and amend the project boundary as appropriate (FERC 2006). However, the Commission does not require land or water associated with one-time measures to become a part of the project boundary (FERC 2006; Union Electric Co., 118 FERC \ 62,247 [2007]).

\section{Example: Approved Settlement Provision-Measures to Add Land Necessary for Project Purposes Requires Redefining the Project Boundary}

In Portland General Electric Co., 133 FERC 9 62,281 (2010), the Commission approved a settlement provision redefining the project boundary for the relicense of a 173-MW hydropower project on the Clackamas River in Oregon. The parties to the agreement proposed expanding the project boundary to incorporate an additional 5.05 acres for aquatic species habitat improvement measures, fish passage facilities, recreation sites, wetland mitigation sites, storage areas for woody debris, areas for implementing gravel augmentation, and roads providing access to project facilities. The Commission reasoned that the proposed expansion measures were necessary "to achieve project purposes... [and] incorporating the lands enclosing these project features into the project boundary [would] provide the necessary access rights over the course of the license term" (Portland General Electric Co., 133 FERC 9 62,281 [2010]).

\section{Example: Approved Settlement Provision-One-Time Measures Do Not Require Land to be Added to the Project Boundary}

In City of Tacoma, Washington, 132 FERC 9 61,037 (2010), the Commission approved a settlement provision regarding a number of recreational improvement projects, outside the project boundary, for the relicense of a 131-MW hydropower project on the Skokomish River in Washington. The parties to the agreement proposed, in part, that the licensee: (1) install a new water system, (2) resurface the campground road, (3) build accessible, double-vault toilets and a fee collection station, (4) provide a trailer dump station, (5) construct an interpretive trail, and (6) add lighting to existing facilities - for the Big Creek Campground. The Big Creek Campground, owned by the U.S. Forest Service, is located about two miles from Lake Cushman, which is impounded by the hydropower project's dam. The Commission approved the settlement provision but did not require that the project boundary be expanded to include the campground. The Commission reasoned that the proposed improvements to the Big Creek Campground, although not within the project boundary, were “...meant to be one-time actions that would not require on-going maintenance, management, monitoring, or oversight by [the City of] Tacoma over the license term” (City of Tacoma, Washington, 132 FERC I 61,037 [2010]).

\section{Removing Land from the Project Boundary}

The Commission may also determine that less land is necessary for the project purpose and remove land from the project boundary (FERC Policy Statement on Hydropower Licensing 
Settlements; Union Electric Co., 118 FERC 9 62,247 (2007) (pdf. 29)). If the Commission removes land from the project boundary, it is placing the land outside of its jurisdiction (Division of Hydropower Administration and Compliance - Compliance Handbook (2015); Union Electric Co., 118 FERC 9 62,247 (2007) (pdf. 29); FERC Policy Statement on Hydropower Licensing Settlements). The Commission may neither impose nor enforce any conditions on the lands removed from the project boundary, nor impose or enforce any covenants running with those lands (Union Electric Co., 118 FERC \ 62,247 (2007) (pdf. 29)).

\section{Example: Approved Settlement Provision--Measures to Remove Land Unnecessary for Project Purposes Requires Redefining the Project Boundary}

In Chugach Electric Association, 120 FERC I 62,148 (2007), the Commission approved a settlement provision redefining the project boundary for the relicense of a 19-MW hydropower project on Cooper Lake in Alaska. The parties to the agreement proposed reducing the project boundary by removing a 90.4-mile-long transmission line. The Commission reasoned that the transmission line did not need to be included in the project boundary because the line "no longer conform[ed] to the Commission's definition of a primary transmission line" because it was "no longer used solely to transmit power from the project.” The Commission conditioned the removal of the transmission line from the project boundary upon the licensee obtaining all necessary federal and state approvals for the transmission line to occupy public lands outside the project boundary (Chugach Electric Association, 120 FERC ๆ 62,148 [2007]).

\section{Example: Rejected Settlement Provision-Measures to Remove Land from the Project Boundary Must Not be Necessary for Project Purposes and Project Effects}

In Union Electric Co., 118 FERC 9 62,247 (2007), the Commission rejected a settlement provision redefining the project boundary for a relicense of a 176-MW hydropower project on the Osage River in Missouri. The parties to the agreement proposed reducing the project boundary by removing 31,000 acres of land around the Lake of the Ozarks. After examining the associated Environmental Assessment (conducted for compliance with NEPA), the Commission found that although the proposal "... would not have a significant direct effect on the aquatic resource habitat or wildlife around the lake...” the removal of the land would likely “...impact both lacustrine and palustrine wetlands...” The Commission reasoned that “...removing lakeshore wetlands from the project boundary would potentially negatively affect these wetlands, because they would not be afforded protection by [the licensee's] existing permitting program and any potential provisions that may be included in a revised Shoreline Management Plan (SMP)," not yet submitted, but required for the relicense. The Commission stated that the licensee may resubmit the request to amend the project boundary when filing the SMP (Union Electric Co., 118 FERC 9 62,247 [2007]).

\subsubsection{Lawful and Enforceable}

The Commission may only exercise the authority granted to it by Congress. The Commission must ensure that the proposed license term or condition is lawful and enforceable. A settlement provision that extends beyond the Commission's jurisdiction cannot become a lawful term or condition of the license, unless required by law (FERC 2006).

\subsubsection{Mandatory Conditions}

The Commission must include mandatory conditions, outside of its jurisdiction, as part of the license if required by law. For instance, the Commission is required to include in the license: 
FPA Section 4(e) mandatory land management conditions, FPA Section 18 mandatory fish prescriptions, FPA Section 30(c) mandatory fish and wildlife conditions (for an exemption from licensing only), and Section 401 of the Clean Water Act (CWA) conditions prescribed in a state water quality certification, unless the term or condition conflicts with the FPA or other law (Pacific Gas and Electric Company, 69 FERC 61,070 [1994]). Similarly, the Commission may not “...delete from the license, in part or in total, a settlement provision (e.g., FPA Section 18 mandatory fish prescriptions) that is beyond the Commission's jurisdiction" unless the provision is counter to law (Avista Corporation, 90 FERC 9 61,167 [2000]).

\section{Example: Rejected Request to Revise License-Mandatory Conditions Are Required by Law}

In Avista Corporation, 93 FERC 61,116 (2000), the Commission, in an order on rehearing, rejected to revise or delete from the license FPA Section 18 fish prescriptions for the relicense of a 697-MW hydropower project on the Clark Fork River in Idaho and Montana. Avista (the licensee) and the Idaho Department of Fish and Game (IDFG) requested that the Commission revise or delete the fish prescription conditions. Avista and IDFG argued the fish prescriptions conditioned by the U.S. Department of Interior (DOI) (i.e., U.S. Fish and Wildlife Service), who was a party to the settlement, did not conform to the timing and scheduling set forth in the agreement. Avista and IDFG argued that the fish prescriptions may encumber the adaptive management approach set forth in the settlement agreement and may not allow adequate analysis of fish passage alternatives. The Commission reasoned that it did not have authority to revise or delete FPA Section 18 prescriptions. The Commission stated that "[b]ecause...the terms of the [settlement] agreement become mandatory license conditions upon th[e] order, [it is] unable to delete from the license those provisions of the settlement that are beyond [its] jurisdiction, in part or in total, to enforce” (Avista Corporation, 93 FERC 61,116 [2000]).

\section{Example: Rejected Mandatory Condition-Mandatory Conditions Contrary to Law Are Unenforceable}

In contrast, in Pacific Gas and Electric Company, 69 FERC 61,070 (1994), the Commission, in an order on rehearing, rejected an FPA Section 4(e) condition for the relicense of a 1.6-MW hydropower project on the Stanislaus River, partly in the Stanislaus Forest in California. The condition, issued by the U.S. Forest Service, required the licensee to obtain a special use authorization before beginning any land-disturbing activities. The Commission found that the Forest Service submitted the 4(e) conditions before the passage of the Energy Policy Act of 1992, which amended Section 501 of the Federal Land Policy and Management Act of 1976 (FLPMA) to add a new subsection. ${ }^{21}$ The new subsection, in part, provided that any licensed or exempted project on federal land that did not receive a right-of-way or other approval did not require one. The Commission reasoned that the “...project ha[d] not previously received a permit, right-of-way or other approval under Section 501 of FLPMA...” and therefore the relicense did not either because it did not involve the use of any additional public lands or National Forest lands. The Commission concluded that the Energy Policy Act barred it from

\footnotetext{
21 The new subsection, in part, provided that “..any project...licensed pursuant to, or granted an exemption from, part I of the Federal Power Act...located on lands subject to a reservation under section 24 of the Federal Power Act and which did not receive a permit, right-of-way or other approval under [the] section prior to the enactment of this subsection, no such permit, right-of-way or other approval shall be required...”
} 
requiring the licensee to obtain a special use authorization (Pacific Gas and Electric Company, 69 FERC 61,070 [1994]).

\subsubsection{Enforcing Terms of the License Through the Licensee}

The Commission can only administer and enforce the terms of the license through the licensee. The Commission cannot enforce settlement provisions against other parties, such as private parties, nongovernmental organizations, or federal and state agencies (FERC 2006). However, in certain circumstances (e.g., dispute resolution terms, conditions imposed by a water quality certification) the Commission has elected to include settlement provisions as license terms or conditions that require parties other than the licensee to comply. The Commission has noted that in these circumstances it does not have the power to enforce the term or condition on the nonlicensee. See Section 2.4.2.5 for more information on dispute resolution settlement provisions.

\section{Example: Rejected Settlement Provision-Measures that Require Enforcement Against Nonlicensees Are Outside of the Commission's Jurisdiction}

In Exelon Generation Company, LLC., 153 FERC 9 62,232 (2015), the Commission rejected a settlement cost-sharing provision for the relicense of an 828-MW hydropower pumped storage project on the Susquehanna River in Pennsylvania. The parties to the agreement proposed that the licensee participate in DOI's eel study and contribute $\$ 75,000$ to DOI for conducting the study. The Commission reasoned that it only has jurisdiction over the licensee, and that "it had no way of ensuring that [DOI] [would] conduct the study.” As a result, the Commission did not require Exelon to pay \$75,000 to [DOI] in the license (Exelon Generation Company, LLC., 153 FERC ๆ 62,232 [2015]). 


\section{Example: Approved Settlement Provision-Measures Are Outside of the Commission's Jurisdiction but Required as Conditions of 401 Water Quality Certification}

In Pepperell Hydro Company, LLC., 152 FERC $\$$ 62,155 (2015), the Commission approved a settlement provision requiring a nonlicensee to manage a fund to reduce and control invasive species for the original license of a 2-MW hydropower project on the Nashua River in Massachusetts. The parties to the agreement proposed that the licensee make 15 annual contributions of $\$ 10,000$ each to the Regional Alliance (nonlicensee) and four additional contributions of \$50,000 each to the Regional Alliance to reduce or control invasive species in the region. In the Environmental Assessment (conducted for compliance with NEPA), the Commission staff reported “...that funding the Regional Alliance [was] not a specific measure with a clear nexus to the project, and that it [was] not clear that the funding would be used to address the invasive species infestation in the project area.” The Commission concluded that the license should not include the funding provision because it only has jurisdiction over the licensee and cannot control the Regional Alliance's use of funds or control measures for the invasive species. In addition, the Commission noted that use of the funds was not restricted to the project area. However, the Commission ultimately included the funding provision in the license because the Section 401 water quality certification included the provision as a license condition (Pepperell Hydro Company, LLC., 152 FERC 9 62,155 [2015]).

\subsubsection{Enforcing Terms of the License Through the Licensee's Property Rights}

The Commission can only administer and enforce the terms of the license through the licensee's property rights. The licensee's property rights should include all lands, waters, and facilities within the project boundary needed to carry out the project purpose (18 C.F.R. $\S \S 4.41 ; 4.92(d)$ ). In addition, the Commission cannot enforce settlement provisions outside the project boundary.

\section{Example: Rejected Settlement Provision-Measures Not Sufficiently Related to the Project Are Beyond the Commission's Jurisdiction}

In Duke Energy Progress, Inc., 151 FERC I 62,004 (2015), the Commission rejected a settlement provision requiring conditions outside the project boundary for the relicense of a 109-MW hydropower project on the Yadkin and Pee Dee Rivers in North Carolina. The parties to the agreement proposed, in part, to adopt the Section 401 water quality certification conditions to: (1) donate and lease to the state of North Carolina certain parcels of undeveloped, nonproject land bordering the Pee Dee River, and (2) place restrictive covenants on nonproject lands located adjacent to project-affected waters. In the Environmental Impact Statement (conducted for compliance with NEPA), the Commission staff "did not recommend the measures pertaining to donating the lands to North Carolina and placing restrictive covenants on non-project lands because the parcels were not necessary for project purposes or to ameliorate a project effect." The Commission reasoned that although the provision was a condition of the certification, it was beyond the scope of the license and did not relate to the project. The Commission stated that although it expected that the licensee would implement the conditions of the water quality certification, they would not become conditions of the license because they were beyond the Commission’s jurisdiction (Duke Energy Progress, Inc., 151 FERC I 62,004 [2015]).

\subsubsection{Monetary Damages}

Under the FPA, the Commission is precluded from imposing monetary damages. Therefore, damage terms or conditions may not be included in a license (16 U.S.C. § 823b[c]). A damages 
term or condition binds settlement parties to pay fines under certain circumstances, such as when a party violates a provision of the settlement agreement. The Commission has consistently declined to include damage provisions as terms or conditions in a license. A settlement provision requiring the licensee or settlement parties to pay damages for violating settlement terms or conditions should be negotiated as part of an off-license agreement, as discussed in Section 3.2.

\section{Example: Rejected Settlement Provision-Measures Requiring the Licensee to Pay Damages Are Contrary to Law}

In Consumers Power Co., 68 FERC 9 61,077 (1994), the Commission rejected a settlement provision requiring the licensee to pay damages to federal and state resource agencies for the relicense of a consolidation of 11 hydropower projects totaling $124 \mathrm{MW}$ on the Au Sable, Mainstee, and Muskegon Rivers in Michigan. The parties to the agreement proposed that the licensee pay money to the U.S. Forest Service, United State Fish and Wildlife Service, and Michigan Department of Natural Resources for project noncompliance with temperature and dissolved oxygen requirements outlined in the settlement agreement. The Commission reasoned "Section 31 of the FPA assigns [the Commission] the authority to assess penalties against licensees for non-compliance with license requirements...not to other federal agencies or to the states" and "the Commission, and only the Commission" is "able to assess penalties against licensees for non-compliance with license orders and terms” (Consumers Power Co., 68 FERC ๆ 61,077 [1994]).

\subsubsection{Enforceability of Specific Types of Settlement Agreement Provisions}

Proposed settlement agreement license terms and conditions often test the bounds of the Commission's jurisdiction, and ultimately the enforceability of those terms and conditions. If a proposed license term or condition is not sufficiently related to a project purpose or effect, associated with an activity within the project boundary, or within the Commission's jurisdiction, then the Commission generally cannot recommend the term or condition be incorporated into the license. Some common license terms and conditions that often present enforceability issues include, but are not limited to:

- Dispute resolution

- Adaptive management

- Recreational enhancements

- $\quad$ Site access

- Cost sharing

- Cost caps

- Funds

- Term length.

\section{Dispute Resolution Provisions}

Historically, the Commission refused to include proposed dispute resolution provisions that included nonlicensees as a license term or condition. The Commission reasoned that the provisions were unenforceable because it only has jurisdiction over a licensee (FERC 2006). The Commission subsequently modified this policy by allowing dispute resolution provisions as a condition of a license to encourage dispute resolution as a means of reducing litigation costs associated with license disputes (FERC 2006). As a result, dispute resolution terms included in a 
license are only enforceable against the licensee, and the Commission can only impose penalties against the licensee for noncompliance. Alternatively, the parties to a settlement agreement may consider negotiating dispute resolution terms in an off-license agreement to effectively bind all relevant parties.

\section{Example: Rejected Dispute Resolution Settlement Provision-Measures Requiring Enforcement Against Nonlicensees Are Outside of the Commission's Jurisdiction}

In Avista Corporation, 93 FERC 61,116 (2000), the Commission rejected a settlement provision requiring dispute resolution terms for the relicense of a 697-MW hydropower project on the Clark Fork River in Idaho and Montana. The parties to the agreement proposed that all signatories to the agreement must be subject to informal negotiations regarding any dispute that arose in the implementation of the agreement, and if an agreement was not reached that the disputing parties must refer the dispute to the Commission (Avista Corporation Cabinet Gorge and Noxon Rapids Hydroelectric Projects Settlement Agreement [1999]). The Commission held that it "had no authority over any signatory other than the licensee and therefore could not enforce compliance of those provisions on all signatories...” (Avista Corporation, 93 FERC 61,116 [2000]).

\section{Example: Approved Dispute Resolution Settlement Provision-Measures Are Outside of the Commission's Jurisdiction but Are Included as Enforceable Only Against the Licensee}

In Erie Boulevard Hydropower, L.P., 100 FERC 9 61,321 (2002), the Commission approved a settlement provision requiring dispute resolution terms for the relicense of several hydropower projects with a combined capacity of $125 \mathrm{MW}$ on the Sacandaga and Hudson Rivers in New York. The parties to the agreement proposed that the licensees report any dispute among the parties regarding the settlement, its terms, or its implementation to the Commission, identifying the subject of the dispute and attempts to resolve it. The Commission stated that it had been the Commission's policy not to incorporate dispute resolution procedures in a license because it lacks authority to enforce such provision against parties other than the licensee. However, in this order, the Commission decided to include the dispute resolution provision in the license. The Commission reasoned that "because dispute resolution can significantly reduce transaction costs of litigation before the Commission over license disputes," it would include the dispute resolution provision in that license, but that the provision would only be enforceable against the licensees (Erie Boulevard Hydropower, L.P., 100 FERC 9 61,321 [2002]).

\section{Adaptive Management Provisions}

An adaptive management term or condition of a FERC authorization allows for measurement adjustments during the term of the license. For example, "[s]ettling parties may agree...that a committee will meet and decide on an annual level of spring flows for fishery purposes” (FERC 2006). Measurement adjustments are based on information gathered from ongoing monitoring of project operations and impacts (FERC 2006). Proposed adaptive management settlement provisions should be closely related to the project purpose and project effects. The provision should include an upper and lower threshold (parameters) for certain actions, and/or provide an opportunity for Commission review before the licensee implements changes. For example, if an adaptive management provision requires a committee to approve and implement varying flows based on ongoing monitoring, the committee may not approve flows outside of the parameters stated in the license because the Commission must have an opportunity to review project operations to ensure they are in the public interest (FERC 2006). 
The Commission has consistently approved adaptive management provisions with upper and lower thresholds, thereby triggering specific activities related to addressing a project purpose or project effects. An adaptive management settlement provision should provide sufficient detail on upper and lower thresholds (parameters) and provide an opportunity for the Commission to review any provisions that trigger activities outside of established parameters. The settlement provision should also provide sufficient information to connect adaptive management measures to a project purpose and project effects.

\section{Example: Rejected Adaptive Management Settlement Provision-Measures Must First Be Approved by the Commission}

In PacifiCorp, 105 FERC \ 62,207 (2003), the Commission rejected a settlement provision requiring modifications to project structures and operations for the relicense of an 85-MW hydropower project on the Bear River in Idaho. The parties to the agreement proposed that the licensee "alter whitewater flow releases" if the flow monitoring indicated that the whitewater releases negatively impacted biological resources. The Commission reasoned that because the proposed adaptive management terms "put project modifications under the direction of the [Environmental Coordination Committee]" and not the Commission, that the proposed adaptive management terms must be amended to provide for Commission approval prior to the Commission incorporating the terms into the license (PacifiCorp, 105 FERC I 62,207 [2003]).

\section{Example: Modified Adaptive Management Settlement Provision-Measures Are Not Clear or Specific}

In Ketchikan Public Utilities, 126 FERC \ 62,205 (2009), the Commission modified a settlement provision requiring adaptive management actions for the relicense of a 5-MW hydropower project on Whitman Creek in Alaska. The parties to the agreement proposed that the licensee implement a dry conditions protocol, and mandate a reduction in instream flows when reservoir levels were low. The Commission found that a modified adaptive management provision would prevent project operations from interfering with hatchery operations and protect aquatic resources. The Commission reasoned that because the licensee "did not indicate a lower threshold level for a reduction in the minimum instream flows" that the Commission would need to modify the proposed adaptive management provision to implement its own lower threshold to incorporate provision into the license (Ketchikan Public Utilities, 126 FERC 9 62,205 [2009]).

\section{Recreational Enhancement Provisions}

A recreation term or condition should be necessary for project purposes, within the project boundary, and supported by substantial evidence (FERC 2006). For example, if a settlement proposes campground enhancements in the project area, the settling parties "should explain how those facilities are used in connection with the project and demonstrate the need for the facilities” (FERC 2006). Recreation terms or conditions may include constructing trails, paths, and facilities associated with boating, fishing, and hiking (FERC 2006).

The Commission has consistently evaluated whether to include proposed recreation measures in a license based on the amount of detail regarding the facility's location and its relation to a project purpose or project effect. The Commission has also generally rejected recreation measures occurring outside of the project boundary. A recreation term or condition should provide sufficient detail regarding the project type, project purpose, and project location. 
Example: Rejected Recreational Enhancement Settlement Provision to Remove Land from the Project Boundary-Land Necessary for Project Purposes and Project Effects

In Wisconsin Public Service Corporation, 104 FERC 9 61,295 (2003), the Commission partially rejected a settlement provision that removed recreation facilities from the project boundary for the relicense of six hydropower projects with a combined capacity of $22 \mathrm{MW}$ on the Peshtigo River in Wisconsin. The parties to the agreement proposed that the licensee remove several boating, camping, fishing, snowmobile, skiing, and biking areas and facilities from the project boundary. The Commission rejected those provisions removing "boating, camping, and fishing areas," reasoning that retaining these recreation facilities within project boundaries would “ensure public access to recreation related to the projects’ reservoirs.” Conversely, the Commission upheld those recreation measures that called for removal of "snowmobile, skiing, and biking trails" because such activities "ha[d] less of a nexus to reservoir-based recreation and [were] found elsewhere in the area” (Wisconsin Public Service Corporation, 104 FERC 9 61,295 [2003]).

\section{Example: Partially Approved Recreational Enhancement Settlement Provision-Removal of Some Measures Outside of the Project Boundary}

In New York Power Authority, 118 FERC \ 61,206 (2007), the Commission partially approved a settlement provision regarding recreational measures for the relicense of a 2,756-MW hydropower project on the Niagara River in New York. The parties to the agreement proposed that the licensee construct "additional parking, walkways, and access improvements for the disabled at three sites within the project boundary" and improve recreation facilities located in the project vicinity, but not in the project boundary. The Commission stated that it would not make the licensee responsible under the license for improving facilities outside the project boundary, but would for improvements to the facilities within the project boundary (New York Power Authority, 118 FERC I 61,206 [2007]).

\section{Site Access Provisions}

A site access (e.g., access road) term or condition should incorporate only the relevant portion of the road that provides necessary access to the project (FERC 2006). Generally, the Commission requires access roads necessary for project purposes to be incorporated into the project boundary (FERC 2006). For example, a provision requiring the licensee to maintain roads that "merely [pass] near the project and [are] used only incidentally for project purposes" may not be included in the license (FERC 2006).

The Commission has generally been consistent in requiring that only roads necessary for a project purpose or to mitigate project effects should be included in the project boundary and incorporated into the license. An access road term or condition should place all roads entirely within the project boundary (FERC 2006; PacifiCorp, 104 FERC 9 62,059 [2003]). The settlement provision should also provide evidence that the access road term or condition requires ongoing maintenance from the licensee and is necessary to meet a project purpose or improve a project effect (see, e.g., Public Utility District No. 1 of Snohomish County, Washington, 136 FERC ๆ 62,188 [2011]).

\section{Example: Rejected Site Access Settlement Provision-Measures Outside of the Project Boundary}


In PacifiCorp, 104 FERC 9 62,059 (2003), the Commission rejected a settlement provision to construct access roads outside the project boundary for the relicense of a 4-MW hydropower project on the Swan River in Montana. The parties to the agreement proposed removing lands from the project boundary that placed access roads, partially or entirely, outside of the project boundary. The Commission held that it could not revise the project boundary because the roads needed to be within the project boundary (PacifiCorp, 104 FERC 9 62,059 (2003) (pdf. 1; 9)).

\section{Example: Approved Site Access Settlement Provision-Mandatory Conditions Are Required by Law}

In Portland General Electric Co., 117 FERC 1 61,112 (2006), the Commission approved a settlement provision requiring the licensee to upgrade and maintain nonproject roads for the relicense of a 367-MW hydropower project on the Deschutes River in Oregon. The parties to the agreement proposed that the licensee would upgrade and maintain "non-project Forest Service and county-owned roads." The Commission found that the roads primarily served other purposes and only incidentally provided access to project facilities and typically could not "be considered necessary for project purposes[.]” However, the Commission included the provisions within the license because the road maintenance and funding provisions were required by the Forest Service's 4(e) mandatory conditions. The Commission included road provisions without finding that the roads were necessary for project purposes or requiring the licensee to incorporate the roads into the project boundary (Portland General Electric Co., 117 FERC 9 61,112 [2006]).

\section{Cost-Sharing Provisions}

Cost-sharing terms and conditions may require licensees and nonlicensees to share the costs associated with completing certain activities required by a license (FERC 2006). For example, some settlement agreements include provisions requiring the "licensee and some other party [to] share the costs of performing certain measures, such as an agreement that the licensee and a federal and state agency will jointly manage a recreation area” (FERC 2006). However, the Commission only has jurisdiction over the licensee, and so it may not enforce cost-sharing measures requiring a nonlicensee to share the costs of performing certain measures. If the Commission requires the licensee to perform a certain measure, "it will look to the licensee alone for performance of that measure” (FERC 2006).

The Commission has been consistent in refusing to incorporate proposed cost-sharing provisions in a license. A licensee may consider negotiating cost-sharing provisions in an off-license agreement to bind nonlicensees to any payment arrangements associated with funding activities related to a project purpose or project effect.

\section{Example: Rejected Cost-Sharing Settlement Provision-Measures Requiring Enforcement Against Nonlicensees Are Outside of the Commission's Jurisdiction}

In Alcoa Power Generating Inc., 110 FERC I 61,056 (2005), the Commission rejected a costsharing settlement provision for the relicense of a 380-MW hydropower project on the Little Tennessee and Cheoah Rivers in North Carolina. The parties to the agreement proposed that the licensee fund a portion of the improvements to recreation facilities and that the Forest Service, North Carolina Wildlife Resources, and Tennessee Wildlife Resources provide additional funding. The Commission reasoned that only the licensee is under its jurisdiction, and only responsible for performing all of the license requirements. As such, the Commission could not 
enforce the proposed recreational enhancement cost-sharing provisions. The Commission required the licensee to resubmit recreational plans specifying those recreational enhancements the licensee was responsible for (Alcoa Power Generating Inc., 110 FERC ๆ 61,056 [2005]).

\section{Cost Cap Provisions}

Cost cap terms and conditions limit the licensee's financial responsibility for completing activities required by a license. For example, some settlement agreements include provisions requiring the licensee to "build a campsite at a cost of $\$ 10,000$ " or "pay $\$ 10,000$ to the state to construct a fishing pier” instead of performing “a particular measure” (FERC 2006). The Commission is primarily concerned with the licensee meeting the requirements of a license regardless of cost and so it generally does not approve spending caps in licensing (FERC 2006). Spending caps interfere with the Commission's ability to enforce license provisions and ensure that project activities are completed. If the Commission includes cost cap provisions in licenses, then it does so only "to memorialize the intent of the parties, but not to approve the limit" (FERC 2006).

The Commission has generally been consistent in rejecting spending limitations associated with cost caps and only including the provisions in licenses to indicate that the licensee has made a commitment to perform a certain activity associated with the project. A cost provision should demonstrate that a spending cap will not limit the licensee's ability to carry out a certain activity. Alternatively, the parties to an agreement may consider negotiating spending caps in an offlicense agreement to bind both licensees and nonlicensees to any payment arrangements related to funding an activity related to a project purpose or effect.

\section{Example: Rejected Cost Cap Settlement Provision-Measures Unlawfully Limit the Licensee's Responsibility and the Commission's Authority}

In New York Power Authority, 105 FERC I 61,102 (2003), the Commission modified a cost cap settlement provision for the relicense of a 912-MW hydropower project on the St. Lawrence River in New York. The parties to the agreement proposed to establish a Shoreline Stabilization Plan that set the licensee's annual expenditure limit at $\$ 500,000$. The Commission reasoned that although it did not think the amount would be insufficient, "agreements among settlement parties to limit a licensee's costs for agreed-upon measures do not limit the Commission’s reserved authority to require additional measures” (New York Power Authority, 105 FERC 9 61,102 [2003]).

\section{Example: Approved Cost Settlement Provision-Measures Are Not a Cost Cap}

In City of Tacoma, Washington, 132 FERC 9 61,037 (2010), the Commission approved a spending settlement provision for the relicense of a 131-MW hydropower project on the Skokomish River in Washington. The parties to the agreement proposed that the licensee initially deposit \$3.5 million dollars into a fund and an additional \$300,000 annually to support aquatic habitat enhancement activities. The Commission reasoned that these contribution requirements were not “a spending limit or cap on [the licensee's] obligations under the plan” and would provide for "the most effective resources protection measures throughout the life of the license” (City of Tacoma, Washington, 132 FERC ๆ 61,037 [2010]). 


\section{Mitigation and Enhancement Fund Provisions}

A fund provision establishes a financial account to support certain activities required by a license. For example, if the project will have an impact on fish populations, a fund provision financing mitigation of those impacts in the project vicinity may be approved and incorporated into a license (FERC 2006). The Commission analyzes fund provisions in relation to its jurisdiction over the licensee, project purpose, and project boundary. The Commission generally approves fund provisions related to environmental enhancement and mitigation if the licensee maintains control over the fund so that the Commission can ensure compliance (FERC 2006).

In evaluating a proposed fund provision, the Commission considers whether the fund has a contribution limit, and whether the Commission can ensure that the fund will be used to pay for activities closely related to a project purpose or effect. A fund provision should remove any contribution limits and provide for licensee control over the fund so that the Commission can ensure compliance. Alternatively, a licensee may consider negotiating fund provisions in an offlicense agreement to bind nonlicensees to any payment arrangements related to funding an activity related to a project purpose or effect.

\section{Example: Approved Fund Settlement Provision-Measures Are Clear and Specific and Sufficiently Related to the Project Purpose and Project Effects}

In Portland General Electric, 133 FERC 92,281 (2010), the Commission approved a funding settlement provision for the relicense of a 173-MW hydropower project on the Clackamas River in Oregon. The parties to the agreement proposed that the licensee would provide \$1.5 million over a 10-year period to Oregon DFW "to stock and monitor hatchery spring Chinook salmon smolts and to develop and implement measures to reduce the impacts of hatchery smolt released on wild fish in the Clackamas River Basin." The Commission stated it "generally does not favor such funds but prefers to require licensees to undertake specific measures to resolve project effects.” However, the Commission reasoned the licensee clearly stated the types of measures that would be funded so that the Commission was "satisfied that the fund [would] be used for environmental measures related to the project.” The Commission approved the funding provision and incorporated the provision into the final license (Portland General Electric, 133 FERC \ 62,281 [2010]).

\section{Example: Rejected Fund Settlement Provision-Measures Are Outside of Commission's Jurisdiction}

In contrast, in Alcoa Power Generating, Inc., 156 FERC 9 62,210 (2016), the Commission rejected a funding settlement provision for the relicense of a 211-MW hydropower project on the Yadkin River in North Carolina. The parties to the agreement proposed that the licensee provide North Carolina Division of Water Resources and the North Carolina Wildlife Resources Commission $\$ 25,000$ annually to support their "efforts to monitor invasive aquatic species at the project's reservoirs." The Commission reasoned it could not incorporate the funding provision into the final license because it could not ensure that the funds provided would be used to "protect or enhance aquatic resources at the project" (Alcoa Power Generating, Inc., 156 FERC ๆ 62,210 [2016]).

\section{License Term Length}

In October 2017, the Commission issued a "Policy Statement on Establishing License Terms for Hydroelectric Projects” establishing a 40-year default license term for original and new licenses 
for hydropower projects at non-federal dams. As part of the new policy, the Commission declared under specific circumstances it will consider license terms of more or less than the 40year default policy. Specifically, the Commission stated it "will defer to a shorter or longer term explicitly agreed upon in a generally-supported comprehensive settlement agreement, provided that such term does not conflict with coordination [with other projects in a basin]. Settlement agreements that state the settlement signatories would not oppose a certain term or would support a term within a range of years will not be considered to include an explicitly agreed upon license term” (FERC 2017). 


\section{Common Settlement Agreement License Terms and Conditions and Off-License Terms}

Section 2 summarized the administrative procedures, legal standards, and enforceability of various types of settlement agreement provisions as terms and conditions of a FERC license (providing illustrative examples as appropriate). In part, based on this foundation, Section 3 provides illustrative examples of the types of provisions that typically become either license terms and conditions or a part of off-license settlement agreements.

\subsection{Common Settlement Agreement License Terms and Conditions}

Settlement agreement terms may vary depending on the number and type of parties, as well as the number and type of unresolved issues. Settlement parties may put forth a comprehensive settlement agreement addressing multiple issues associated with a FERC authorization (see, e.g., PPL Holtwood, LLC, Offer of Settlement and Explanatory Statement [2009]). Alternatively, settlement parties may narrowly tailor the agreement to focus on a single issue (see, e.g., Settlement Agreement Addressing Federal Power Act Section 4(e) Mandatory Conditions for Spokane River Project, FERC No. 2545 [2009]).

Settlement agreements are commonly negotiated between developers (licensees), federal and state land management agencies, ${ }^{22}$ federal and state resource agencies, ${ }^{23}$ nongovernmental organizations, ${ }^{24}$ and other interested stakeholders. In some instances, multiple licensees negotiate settlement agreements to resolve issues associated with relicensing impacts on hydropower projects located within the same watershed (see, e.g., Relicensing Settlement Agreement for the Upper American River Project and Chili Bar Hydroelectric [2007]).

Parties commonly negotiate terms relating to flow level and management; species habitat and protection; adaptive management; water quality; recreation; creating conversation easements; mitigation and enhancement funds; dispute resolution; and preservation of historic properties.

\subsubsection{Flow Level and Management}

In the Relicensing Settlement Agreement for the Santee Cooper Project (2007), the settlement agreement parties including the U.S. Fish and Wildlife Service, the South Carolina Department of Natural Resources, and the South Carolina Public Service Authority (licensee), negotiated terms for minimum instream flows for the relicense of a hydropower project located on the Santee and Cooper Rivers in South Carolina. The minimum instream flow provision required the licensee to maintain a minimum flow of 2,400 cubic feet per second February through April and 1,200 cubic feet per second May through January at the Santee Dam. This settlement agreement was fairly limited in scope because the parties chose to strictly focus on resolving issues related

\footnotetext{
${ }^{22}$ Land management agencies commonly involved in settlement negotiations include but are not limited to: U.S. Department of Interior, Bureau of Land Management, National Park Service, Bureau of Indian Affairs, local governments, individuals, American Indian tribes, state departments of parks and recreation, and state departments of natural resources.

${ }^{23}$ Federal and state resource agencies commonly involved in settlement agreement negotiations include but are not limited to: U.S. Fish and Wildlife Service, U.S. Forest Service, state departments of ecology (health and environmental control), state departments of fish and game (wildlife), and state departments of water quality (water resources).

${ }^{24}$ Nongovernmental organizations commonly involved in settlement negotiations include but are not limited to: fish protection groups (e.g., Trout Unlimited, fisherman's associations), water protection groups (e.g., Friends of the River, water users associations), environmental protection groups (e.g., nature conservancies), and outdoor groups (e.g., American Whitewater).
} 
to instream flow and fish passage (Relicensing Settlement Agreement for the Santee Cooper Project [2007]). ${ }^{25}$

\subsubsection{Species and Habitat Protection}

In the Settlement Agreement for the Henry M. Jackson Hydroelectric Project (2009), the settlement agreement parties including federal and state resource agencies, local governments, a tribal government, a nongovernmental organization, and the Public Utility District No. 1 of Snohomish County, Washington (licensee), negotiated terms for water temperature conditions related to species protection for the relicense of a hydropower project on the Sultan River in Washington. The parties to the agreement proposed that the licensee would develop "temperature conditioning performance standards” most suitable for salmonids, as well as other fish and macroinvertebrates. In addition to species habitat and protection, the settlement agreement addressed several issues relating to aquatic resources, adaptive management, instream flow, historic properties, recreation, terrestrial resources, and water quality (Settlement Agreement for the Henry M. Jackson Hydroelectric Project [2009]). The Commission included these temperature conditioning provisions in the final license as Article 415 and Section 4(e) mandatory condition no. 2 (Public Utility District No. 1 of Snohomish County, Washington, 136 FERC \ 62,188 [2011]).

\subsubsection{Adaptive Management}

In the Aquatic Settlement Agreement Wells Hydroelectric Project FERC License No. 2149 (2010), the settlement agreement parties including federal and state resource agencies, federal land management agencies, tribal governments, and Public Utility District No. 1 of Douglas County, Washington (licensee), negotiated adaptive management terms and conditions relating to aquatic resource management for the relicense of a hydropower project on the Columbia River in Washington. The parties to the agreement proposed that the licensee would implement "Aquatic Resource Management Plans” including adaptive management procedures for adjusting project operations based on information gathered by identifying, testing, and addressing project impacts. This settlement agreement was narrow in scope because the parties chose to focus primarily on resolving issues related to aquatic resource management (Aquatic Settlement Agreement Wells Hydroelectric Project FERC License No. 2149 [2010]). The Commission incorporated this adaptive management strategy into the license as Section 401 water quality certification conditions. In addition, in license Article 403, the Commission modified the proposed adaptive management provisions by requiring the licensee to "notify the Commission within 48 hours of any temporary modifications to approved project operations or facilities that are necessary to protect aquatic resources” (Public Utility District No. 1 of Douglas County, Washington, 141 FERC ๆ 62,104 [2012]).

\subsubsection{Water Quality}

In the Settlement Agreement Addressing Federal Power Act Section 4(e) Mandatory Conditions for Spokane River Project, FERC No. 2545 (2009), the settlement agreement parties including the Coeur d'Alene Tribe, and DOI on behalf of the Bureau of Indian Affairs, and Avista Corporation (licensee), negotiated mandatory 4(e) conditions relating to water quality for the relicense of a 138-MW hydropower project on the Spokane River in Washington and Idaho. The parties to the agreement proposed that the licensee would develop and file with the Commission, a Water Quality Monitoring Plan. The provision also required the licensee to implement the plan

${ }^{25}$ FERC has not issued a final order on relicensing for this project. 
by monitoring water temperature, dissolved oxygen, and $\mathrm{pH}$ at specific sites, as well as gathering and analyzing water samples. This settlement agreement was fairly narrow in scope because the parties chose to focus only on resolving issues related to 4(e) conditions under the FPA (Settlement Agreement Addressing Federal Power Act Section 4(e) Mandatory Conditions for Spokane River Project, FERC No. 2545 [2009]). Although the Commission reasoned that the licensee should only be required to monitor water temperature and dissolved oxygen, it ultimately included the entire Water Quality Monitoring Plan in the final license as a mandatory 4(e) condition (Avista Corporation, 127 FERC ๆ 61,265 [2009]).

\subsubsection{Recreational Enhancements}

In the Relicensing Settlement Agreement for the Upper American River Project and Chili Bar Hydroelectric Project (2007), the settlement agreement parties including several federal and state resources agencies, nongovernmental organizations, private individuals, the Sacramento Municipal Utility District, and Pacific Gas and Electric Company (licensees), negotiated terms associated with recreation for the relicense of two separate hydropower projects on the American River in California. The parties to the agreement for the Upper American River Project proposed that the licensee would develop a recreation implementation plan, conduct a recreation survey, and implement measures at specific recreation sites including, but not limited to:

- Improving or relocating trails

- Preparing development plans

- Installing bear-proof lockers

- Reconstructing campgrounds to meet American with Disabilities Act requirements

- Constructing parking areas.

In addition to recreation, this settlement agreement addressed several issues related to minimum instream flows, aquatic resource management, wildlife and plant protection, and adaptive management associated with two hydropower projects undergoing separate relicensing processes (Relicensing Settlement Agreement for the Upper American River Project and Chili Bar Hydroelectric Project [2007]). Although the Commission recommended not incorporating those recreation provisions imposing cost caps or funding restrictions, the Commission ultimately included these recreation provisions in the final license as mandatory 4(e) conditions (Sacramento Municipal Utility District, 148 FERC ๆ 62,070 [2014]).

\subsubsection{Conservation Easements}

In the Settlement Agreement for the Saccarappa Project (2016), the settlement agreement parties including several federal and state resources agencies, two nongovernmental organizations, a municipality, and the S.D. Warren Company (licensee) negotiated a conservation easement agreement for the surrender of a hydropower project on the Presumpcot River in Maine. The parties to the agreement proposed to restrict the use of land near the project site to protect and preserve "in perpetuity the safe, timely, and effective passage of diadromous fish" and prohibited any use of the easement impairing or interfering with such purpose. In addition to conservation easements, this settlement agreement addressed several issues relating to fish passage, fish stocking, construction, operation and maintenance, and dispute resolution (Settlement Agreement for the Saccarappa Project [2016]). ${ }^{26}$

${ }^{26}$ FERC has not issued a final order on the surrender for this project. 


\subsubsection{Mitigation and Enhancement Funds}

In the York Haven Hydroelectric Project Offer of Settlement (2014), the settlement agreement parties including federal and state resource agencies, a nongovernmental organization, and the York Haven Power Company (licensee), negotiated a funding provision for the relicense of a hydropower project on the Susquehanna River in Pennsylvania and Maryland. The parties to the agreement proposed that the licensee would "provide an annual contribution of $\$ 25,000 \ldots$ to the York County Conservation District" used and administered "for the sole purpose of debris removal in the Lower Susquehanna River Watershed.” This settlement agreement was fairly narrow in scope because the parties chose to focus on resolving issues related to fish passage (York Haven Hydroelectric Project Offer of Settlement [2014]). Although the Commission recommended not including this funding provision in the final license because it did not appear "to be related to any specific project effect[,]" the Commission included the provision in the final license as a Section 401 water quality certification condition (York Haven Power Co., LLP, 153 FERC \ 62,233 [2014]).

\subsubsection{Dispute Resolution}

In the PPL Holtwood, LLC, Offer of Settlement and Explanatory Statement (2009), the settlement agreement parties including Exelon Generation and PPL Holtwood (licensee) negotiated terms for dispute resolution for the relicense of a hydropower project on the Susquehanna River in Pennsylvania. The parties to the agreement proposed that they would first attempt to resolve disputes arising under the settlement agreement informally through discussion prior to initiating the formal dispute resolution procedure. In addition to dispute resolution, this settlement agreement addressed several issues related to project boundary, land management, debris management, minimum flows, and aquatic resources (PPL Holtwood, LLC Offer of Settlement and Explanatory Statement [2009]). ${ }^{27}$

\subsubsection{Preservation of Historic Properties}

In the Cabin Creek Pumped Storage Hydroelectric Project FERC Project No. 2351 Final Settlement Agreement (2013), the settlement agreement parties including federal and state resource agencies, and the Public Service Company of Colorado (licensee), negotiated settlement terms regarding management of historic properties for the relicense of a hydropower project on South Clear Creek and Cabin Creek in Colorado. ${ }^{26}$ The parties to the agreement proposed that the licensee would implement a Programmatic Agreement including a Historic Properties Management Plan for the project to protect six archaeological sites and several historic buildings. In addition to historic properties, this settlement agreement addressed several issues relating to flow levels, water quality management, habitat protection and management, road maintenance, recreation, and dispute resolution (Cabin Creek Pumped Storage Hydroelectric Project FERC Project No. 2351 Final Settlement Agreement [2013]). The Commission included these historic properties management provisions in the final license in Article 407 and as Forest Service 4(e) condition 40 in compliance with Section 106 of the National Historic Preservation Act (Public Service Company of Colorado, 147 FERC \ 62,157 [2014]).

\footnotetext{
${ }^{27}$ FERC has not issued a final order on the surrender for this project.

${ }^{26}$ Of the negotiating parties, only the licensee and the U.S. Forest Service signed the settlement agreement.
} 


\subsection{Common Off-License Settlement Agreement Terms}

Settlement agreement parties often negotiate on- and off-license agreements in a single comprehensive settlement agreement (see, e.g., Settlement Agreement for the Cushman Project, [2009]). ${ }^{28}$ Off-license agreements include terms that the parties do not intend for inclusion in the final license (see, e.g., Cabin Creek Pumped Storage Hydroelectric Project FERC Project No. 2351 Final Settlement Agreement [2013]). ${ }^{29}$ The Commission encourages parties to negotiate terms that are outside of the Commission's jurisdiction in off-license agreements (FERC 2006).

However, if the Commission reviews off-license terms as part of a comprehensive settlement agreement, it may incorporate the intended off-license term into the final license (see, e.g., Alcoa Power Generating, Inc., 156 FERC $\$$ 62,210 [2016]). ${ }^{30}$ In addition, if the off-license agreement is included as a mandatory condition in the license application, then the Commission is required to include the term in the final license (see, e.g., New York Power Authority, 118 FERC 9 61,206 [2007]). ${ }^{31}$

Commonly negotiated off-license terms often involve issues related to project financing or compensation and include mitigation and enhancement funding provisions, cost-sharing provisions, and damages provisions.

\subsubsection{Mitigation and Enhancement Funds}

In the Oswegatchie River Project Offer of Settlement (2011), the settlement agreement parties, including federal and state resource agencies, federal and state land management agencies, a municipality, nongovernmental organizations, and Erie Boulevard Hydropower, L.P. (licensee), included an off-license mitigation and enhancement provision as part of a comprehensive settlement agreement for the relicense of a hydropower facility on the Oswegatchie River in New York. The parties to the off-license agreement proposed that the licensee would establish a "River Management Fund" and contribute \$2,000 per year to be used for "projects, studies, or services" for ecosystem restoration, environmental stewardship, public education, research and development, and recreational development (Oswegatchie River Project Offer of Settlement [2011]). The Commission did not include this off-license mitigation and enhancement provision in the final license (Oswegatchie River Hydroelectric Project, 141 FERC I 62,125 [2012]).

In the Yakin Hydroelectric Project Relicensing Settlement Agreement (2007), the settlement agreement parties including federal and state resource agencies, state land managers, an American Indian Tribe, municipalities, nongovernmental organizations, and Alcoa Power Generating Inc. (licensee), included an invasive species monitoring and funding off-license provision as part of a comprehensive settlement agreement for the relicense of a hydropower project on the Yadkin River in North Carolina. The parties to the off-license agreement proposed

\footnotetext{
${ }^{28}$ Settlement parties included three off-license agreements in their comprehensive settlement for relicensing including a damages agreement between the licensee and the Skokomish Tribe, a fish stocking agreement between the licensee and the Washington Department of Fish and Wildlife, and a cost-sharing agreement between the licensee and U.S. Forest Service.

${ }^{29}$ Settlement parties included an off-license agreement between the licensee and the U.S. Forest Service in its comprehensive settlement agreement for relicensing, but "it [was] not intended that [this off-license agreement] be included as a license condition or enforced by FERC. Rather the [agreement was] included for FERC’s informational purposes only.”

${ }^{30}$ Settlement parties included off-license measures in its comprehensive settlement agreement for relicensing regarding funding the North Carolina Department of Water Resources efforts to monitor invasive species. Upon review, the Commission rejected the off-license funding provision, but incorporated the off-license invasive species monitoring provisions into the final license. ${ }^{31}$ An off-license settlement term was included in a final license as a mandatory water quality certification condition despite the parties' intent, and the Commission's recommendation, not to include the provision in the final license.
} 
that the licensee would make a \$25,000 annual contribution to the North Carolina Department of Water Resources (NCDWR) or North Carolina Water Resources Council (NCWRC) to fund efforts to monitor invasive species. The off-license provision also stated that the licensee would "work in cooperation with the NCDWR and NCWRC to monitor invasive exotic species of concern at the project” (Yakin Hydroelectric Project Relicensing Settlement Agreement [2007]). The Commission did not include the off-license provision funding the NCWRC or NCDWR's invasive species monitoring efforts in the final license, but did include the off-license provision requiring the licensee to monitor invasive species in Article 404 because monitoring these invasive species "would provide information about the effects of water quality and project operations” on invasive species “recruitment” (Alcoa Power Generating, Inc., 156 FERC 9 62,210 [2016]).

\subsubsection{Cost Sharing}

In the Relicensing Settlement Agreement for the Upper American River Project and the Chili Bar Hydroelectric Project (2007), some of the settlement agreement parties, including the Bureau of Land Management (BLM), Sacramento Municipal Utility District (SMUD) (licensee), and Pacific Gas and Electric (PG\&E) (licensee), included an off-license agreement to share costs supporting the BLM's operation and maintenance of recreation facilities as part of a comprehensive settlement agreement for the relicense of two hydropower projects on the Upper American River in California. The parties to the off-license agreement proposed that SMUD would be required to "make a one-time payment" of $\$ 270,000$ to the BLM as well as future payments of $\$ 270,000$ annually, as adjusted. The off-license provision also stated that PG\&E would make “a one-time payment of $\$ 30,000$ ” to the BLM as well as future payments of $\$ 30,000$ annually, as adjusted. (Relicensing Settlement Agreement for the Upper American River Project and the Chili Bar Hydroelectric Project [2007]).

\subsubsection{Damages Provisions}

In the Settlement Agreement for the Cushman Project (2009), some of the settlement agreement parties, including the Skokomish Tribe and the City of Tacoma Washington (licensee), included an off-license damages agreement as part of a comprehensive settlement agreement for the relicense of a hydropower project on the Skokomish River in Washington. The parties to the offlicense agreement proposed that the licensee would be required to pay the Skokomish Tribe "six million dollars... as partial compensation for the Tribe's damages" and "five million dollars...for projects or actions related to the mitigation of flooding impacts on the Skokomish Indian Reservation” (Settlement Agreement for the Cushman Project [2009]. The Commission did not include these off-license damages provisions in the final license. (City of Tacoma, Washington, 132 FERC I 61,037 [2010]).

In the Ludington Pumped Storage Project Relicensing Settlement Agreement (2017), the settlement agreement parties, including federal and state resource agencies, a state administrative agency, several American Indian Tribes, nongovernmental organizations, Consumers Energy Company (licensee), and DTE Electric Company (licensee), included an off-license compensation and mitigation agreement as part of a comprehensive settlement agreement for the relicense of a hydropower project on Lake Michigan in Mason County, Michigan. The parties to the off-license agreement proposed that the licensees would deposit damages for fish mortality associated with the hydropower project into a trust account administered by the nonlicensee settlement parties for conducting research, rehabilitating fish species, and protecting and 
enhancing fisheries habitat (Ludington Pumped Storage Project Relicensing Settlement Agreement [2017]). ${ }^{32}$

32 FERC has not issued a final order on the surrender for this project. 


\section{Summary-Conclusion}

This section summarizes the enforceability of various types of settlement agreement provisions and provides examples of how settlement agreement parties have incorporated these provisions as license terms and conditions and off-license terms. Table 1 provides a summary of proposed settlement agreement license terms and conditions that have tested the bounds of the Commission's jurisdiction, and ultimately the enforceability of those terms and conditions. Table 2 provides a summary of common settlement agreement topics that parties include in settlement agreements as proposed license terms and conditions and/or as off-license terms.

Table 1. Summary of the Enforceability of Proposed Settlement Agreement License Terms and Conditions

\begin{tabular}{|c|c|c|c|c|c|}
\hline $\begin{array}{c}\text { Type of } \\
\text { Settlement } \\
\text { Agreement } \\
\text { Provision } \\
\end{array}$ & $\begin{array}{l}\text { Applicable Commission } \\
\text { Enforceability Policy }\end{array}$ & $\begin{array}{l}\text { Order Stating Commission } \\
\text { Enforceability Policy }\end{array}$ & $\begin{array}{l}\text { Example of Proposed or } \\
\text { Actual Inclusion as License } \\
\text { Term or Condition }\end{array}$ & $\begin{array}{c}\text { Example of Proposed or } \\
\text { Actual Inclusion as Off- } \\
\text { License Agreement } \\
\text { Provision }\end{array}$ & $\begin{array}{l}\text { Considerations/ } \\
\text { Exceptions }\end{array}$ \\
\hline $\begin{array}{l}\text { Dispute } \\
\text { Resolution }\end{array}$ & $\begin{array}{l}\text { Traditionally dispute } \\
\text { resolution provisions are } \\
\text { outside of the scope of a } \\
\text { license. However, the } \\
\text { Commission has held that } \\
\text { dispute resolution provisions } \\
\text { may be included in a license } \\
\text { but are only enforceable } \\
\text { against the licensee. }\end{array}$ & $\begin{array}{l}\text { Avista Corporation, } 93 \text { FERC } \\
61,116 \text { (2000) (rejection of } \\
\text { dispute resolution settlement } \\
\text { provision); Erie Boulevard } \\
\text { Hydropower, L.P., } 100 \text { FERC } 9 \\
61,321 \text { (2002) (approval of } \\
\text { dispute resolution settlement } \\
\text { provision, but only as } \\
\text { enforceable against the } \\
\text { licensees) }\end{array}$ & $\begin{array}{l}\text { PPL Holtwood, LLC, Offer of } \\
\text { Settlement and Explanatory } \\
\text { Statement, (2009)* }\end{array}$ & & $\begin{array}{l}\text { The parties to a settlement } \\
\text { agreement may consider } \\
\text { negotiating dispute resolution } \\
\text { terms in an off-license agreement } \\
\text { to effectively bind all parties. }\end{array}$ \\
\hline $\begin{array}{l}\text { Adaptive } \\
\text { Management }\end{array}$ & $\begin{array}{l}\text { Adaptive management } \\
\text { provisions may be included in } \\
\text { a license. However, adaptive } \\
\text { management provisions } \\
\text { should be closely related to } \\
\text { the project purpose and } \\
\text { effects, include an upper and } \\
\text { lower threshold (parameters) } \\
\text { for certain actions, and/or } \\
\text { provide an opportunity for } \\
\text { Commission review before } \\
\text { the licensee implements } \\
\text { changes. }\end{array}$ & $\begin{array}{l}\text { PacifiCorp, } 105 \text { FERC } 962,207 \\
\text { (2003) (rejection of adaptive } \\
\text { management settlement } \\
\text { provision not requiring } \\
\text { Commission approval for project } \\
\text { modifications); Ketchikan Public } \\
\text { Utilities, } 126 \text { FERC } 962,205 \\
\text { (2009) (modification of adaptive } \\
\text { management settlement } \\
\text { provision to incorporate lower } \\
\text { threshold for instream flow } \\
\text { reductions) }\end{array}$ & $\begin{array}{l}\text { Aquatic Settlement } \\
\text { Agreement Wells } \\
\text { Hydroelectric Project FERC } \\
\text { License No. } 2149 \text { (2010) for } \\
\text { license order Public Utility } \\
\text { District No. } 1 \text { of Douglas } \\
\text { County, Washington, } 141 \\
\text { FERC } 962,104 \text { (2012) }\end{array}$ & & $\begin{array}{l}\text { If an adaptive management } \\
\text { provision falls outside of } \\
\text { preapproved parameters in the } \\
\text { license, the Commission must have } \\
\text { an opportunity to review any of } \\
\text { the adaptive management } \\
\text { requirements. }\end{array}$ \\
\hline
\end{tabular}




\begin{tabular}{|c|c|c|c|c|c|}
\hline $\begin{array}{c}\text { Type of } \\
\text { Settlement } \\
\text { Agreement } \\
\text { Provision }\end{array}$ & $\begin{array}{l}\text { Applicable Commission } \\
\text { Enforceability Policy }\end{array}$ & $\begin{array}{l}\text { Order Stating Commission } \\
\text { Enforceability Policy }\end{array}$ & $\begin{array}{l}\text { Example of Proposed or } \\
\text { Actual Inclusion as License } \\
\text { Term or Condition }\end{array}$ & $\begin{array}{l}\text { Example of Proposed or } \\
\text { Actual Inclusion as Off- } \\
\text { license Agreement } \\
\text { Provision }\end{array}$ & $\begin{array}{l}\text { Considerations/ } \\
\text { Exceptions }\end{array}$ \\
\hline $\begin{array}{l}\text { Recreational } \\
\text { Enhancements }\end{array}$ & $\begin{array}{l}\text { Recreational enhancement } \\
\text { provisions may be included in } \\
\text { a license, but should be } \\
\text { necessary for project } \\
\text { purposes, within the project } \\
\text { boundary, and supported by } \\
\text { substantial evidence. }\end{array}$ & $\begin{array}{l}\text { Wisconsin Public Service } \\
\text { Corporation, } 104 \text { FERC } 961,295 \\
\text { (2003) (partial rejection of } \\
\text { recreational enhancement } \\
\text { settlement provision seeking } \\
\text { removal of boating, camping, } \\
\text { and fishing areas from the } \\
\text { project boundary); New York } \\
\text { Power Authority, } 118 \text { FERC } 9 \\
61,206 \text { (2007) (partial approval } \\
\text { of recreational enhancement } \\
\text { settlement provision requiring } \\
\text { additional parking, walkways, } \\
\text { and improvement for the } \\
\text { disabled within project } \\
\text { boundary) }\end{array}$ & $\begin{array}{l}\text { Relicensing Settlement } \\
\text { Agreement for the Upper } \\
\text { American River Project and } \\
\text { Chili Bar Hydroelectric } \\
\text { Project (2007) for license } \\
\text { order Sacramento } \\
\text { Municipal Utility District, } \\
148 \text { FERC } \uparrow 62,070 \text { (2014) }\end{array}$ & & $\begin{array}{l}\text { The Commission has generally } \\
\text { rejected recreation measures } \\
\text { occurring outside of the project } \\
\text { boundary. }\end{array}$ \\
\hline Site Access & $\begin{array}{l}\text { Site access provisions may be } \\
\text { included in a license, but only } \\
\text { the roads necessary to a } \\
\text { project purpose or to mitigate } \\
\text { project effects should be } \\
\text { included in the project } \\
\text { boundary and incorporated } \\
\text { into the license. }\end{array}$ & $\begin{array}{l}\text { PacifiCorp, } 104 \text { FERC } 962,059 \\
\text { (2003) (rejection of site access } \\
\text { settlement provision to } \\
\text { construct roads outside the } \\
\text { project boundary) }\end{array}$ & & & $\begin{array}{l}\text { In Portland General Electric Co., } \\
117 \text { FERC } 961,112 \text { (2006), the } \\
\text { Commission included "nonproject" } \\
\text { U.S. Forest Service and county- } \\
\text { owned roads outside of the license } \\
\text { boundary, despite not being } \\
\text { considered necessary for project } \\
\text { purposes, because the road } \\
\text { maintenance and funding } \\
\text { provisions were required by the } \\
\text { U.S. Forest Service's } 4(\mathrm{e}) \\
\text { mandatory conditions. }\end{array}$ \\
\hline
\end{tabular}




\begin{tabular}{|c|c|c|c|c|c|}
\hline $\begin{array}{c}\text { Type of } \\
\text { Settlement } \\
\text { Agreement } \\
\text { Provision }\end{array}$ & $\begin{array}{l}\text { Applicable Commission } \\
\text { Enforceability Policy }\end{array}$ & $\begin{array}{l}\text { Order Stating Commission } \\
\text { Enforceability Policy }\end{array}$ & $\begin{array}{l}\text { Example of Proposed or } \\
\text { Actual Inclusion as } \\
\text { License Term or } \\
\text { Condition }\end{array}$ & $\begin{array}{c}\text { Example of Proposed } \\
\text { or Actual Inclusion as } \\
\text { Off-license Agreement } \\
\text { Provision }\end{array}$ & $\begin{array}{l}\text { Considerations/ } \\
\text { Exceptions }\end{array}$ \\
\hline Cost Sharing & $\begin{array}{l}\text { Cost-sharing provisions that } \\
\text { require nonlicensees to share } \\
\text { the costs associated with } \\
\text { completing license } \\
\text { requirements are generally } \\
\text { beyond the Commission's } \\
\text { authority. Typically, the } \\
\text { Commission only has } \\
\text { jurisdiction over the licensee, } \\
\text { and as such may not enforce } \\
\text { cost-sharing measures } \\
\text { requiring a nonlicensee to } \\
\text { share the costs of performing } \\
\text { license terms or conditions. }\end{array}$ & $\begin{array}{l}\text { Alcoa Power Generating Inc., } \\
110 \text { FERC } 961,056 \text { (2005) } \\
\text { (rejection of cost-sharing } \\
\text { settlement provision because } \\
\text { Commission does not have } \\
\text { jurisdiction over nonlicensees } \\
\text { included in the agreement) }\end{array}$ & & & $\begin{array}{l}\text { A licensee may consider } \\
\text { negotiating cost-sharing } \\
\text { provisions in an off-license } \\
\text { agreement to bind nonlicensees } \\
\text { to any payment arrangements } \\
\text { related to funding activities } \\
\text { related to a project purpose or } \\
\text { effect. }\end{array}$ \\
\hline Cost Caps & $\begin{array}{l}\text { Cost cap provisions are } \\
\text { generally discouraged and not } \\
\text { enforced by the Commission. } \\
\text { The Commission has been } \\
\text { consistent in rejecting } \\
\text { spending limitations } \\
\text { associated with cost caps and } \\
\text { only including the provisions } \\
\text { in licenses to indicate that the } \\
\text { licensee has made a } \\
\text { commitment to perform a } \\
\text { certain activity associated } \\
\text { with the project. }\end{array}$ & $\begin{array}{l}\text { New York Power Authority, } 105 \\
\text { FERC } 9 \text { 61,102 (2003) } \\
\text { (modification to cost cap } \\
\text { settlement provision to } \\
\text { eliminate limit for licensee's } \\
\text { costs to implement agreed-upon } \\
\text { measures); City of Tacoma, } \\
\text { Washington, } 132 \text { FERC } 961,037 \\
\text { (2010) (approval of settlement } \\
\text { provision for cost amounts not } \\
\text { intended to serve as a cap on } \\
\text { spending) }\end{array}$ & & $\begin{array}{l}\text { Relicensing Settlement } \\
\text { Agreement for the } \\
\text { Upper American River } \\
\text { Project and the Chili Bar } \\
\text { Hydroelectric Project, } \\
\text { (2007) }\end{array}$ & $\begin{array}{l}\text { In City of Tacoma, Washington, } \\
132 \text { FERC } 9 \text { 61,037 (2010), the } \\
\text { Commission approved a spending } \\
\text { amount settlement agreement } \\
\text { provision for the relicense of a } \\
\text { 131-MW hydropower project on } \\
\text { the Skokomish River in } \\
\text { Washington because the } \\
\text { Commission held the included } \\
\text { costs were not meant to serve as } \\
\text { a spending limit or cap. } \\
\text { The parties to an agreement may } \\
\text { consider negotiating spending } \\
\text { caps in an off-license agreement } \\
\text { to bind both licensees and } \\
\text { nonlicensees to any payment } \\
\text { arrangements associated with } \\
\text { funding an activity related to a } \\
\text { project purpose or effect. }\end{array}$ \\
\hline
\end{tabular}




\begin{tabular}{|c|c|c|c|c|c|}
\hline $\begin{array}{c}\text { Type of } \\
\text { Settlement } \\
\text { Agreement } \\
\text { Provision }\end{array}$ & $\begin{array}{l}\text { Applicable Commission } \\
\text { Enforceability Policy }\end{array}$ & $\begin{array}{l}\text { Order Stating Commission } \\
\text { Enforceability Policy }\end{array}$ & $\begin{array}{c}\text { Example of Proposed or } \\
\text { Actual Inclusion as } \\
\text { License Term or } \\
\text { Condition }\end{array}$ & $\begin{array}{c}\text { Example of Proposed } \\
\text { or Actual Inclusion as } \\
\text { Off-license Agreement } \\
\text { Provision }\end{array}$ & $\begin{array}{l}\text { Considerations/ } \\
\text { Exceptions }\end{array}$ \\
\hline $\begin{array}{l}\text { Mitigation and } \\
\text { Enhancement } \\
\text { Funds }\end{array}$ & $\begin{array}{l}\text { Fund provisions establishing a } \\
\text { financial account to support } \\
\text { license activities may be } \\
\text { included in a license. The } \\
\text { Commission generally } \\
\text { approves fund provisions } \\
\text { related to environmental } \\
\text { enhancement and mitigation } \\
\text { if the licensee maintains } \\
\text { control over the fund so that } \\
\text { the Commission can ensure } \\
\text { compliance. }\end{array}$ & $\begin{array}{l}\text { Portland General Electric, } 133 \\
\text { FERC } 962,281 \text { (2010) (approval } \\
\text { of funding settlement provision } \\
\text { where licensee clearly stated } \\
\text { the types of measures to be } \\
\text { funded to the satisfaction of the } \\
\text { Commission); Alcoa Power } \\
\text { Generating, Inc., } 156 \text { FERC } 9 \\
62,210 \text { (2016) (rejection of } \\
\text { funding settlement provision } \\
\text { due to the Commission's } \\
\text { inability to ensure intended use } \\
\text { of the funds) }\end{array}$ & $\begin{array}{l}\text { York Haven Hydroelectric } \\
\text { Project Offer of } \\
\text { Settlement (2014) for } \\
\text { license order York Haven } \\
\text { Power Co., LLP, } 153 \text { FERC } \\
\text { ๆ 62,233 (2014) (funding } \\
\text { provision included } \\
\text { pursuant to CWA Section } \\
\text { 401, despite lacking a } \\
\text { nexus to a specific project } \\
\text { effect) }\end{array}$ & & $\begin{array}{l}\text { A fund provision should remove } \\
\text { any contribution limits and } \\
\text { provide licensee with control } \\
\text { over the fund so that the } \\
\text { Commission can ensure } \\
\text { compliance. } \\
\text { Alternatively, a licensee may } \\
\text { consider negotiating fund } \\
\text { provisions in an off-license } \\
\text { agreement to bind nonlicensees } \\
\text { to any payment arrangements } \\
\text { associated with funding an } \\
\text { activity related to a project } \\
\text { purpose or effect. }\end{array}$ \\
\hline $\begin{array}{l}\text { License Term } \\
\text { Length }\end{array}$ & $\begin{array}{l}\text { License term length } \\
\text { provisions establishing } \\
\text { shorter or longer terms than } \\
\text { the } 40 \text {-year default policy for } \\
\text { hydropower projects at non- } \\
\text { federal dams may be included } \\
\text { in a license. The Commission } \\
\text { will approve these terms if } \\
\text { they are explicitly agreed } \\
\text { upon in a generally-supported } \\
\text { comprehensive settlement } \\
\text { agreement. }\end{array}$ & $\begin{array}{l}\text { Policy Statement on Establishing } \\
\text { License Terms for Hydroelectric } \\
\text { Projects, } 161 \text { FERC } 961,078 \\
\text { (2017) (adopting a 40-year } \\
\text { default license term for original } \\
\text { and new licenses for } \\
\text { hydropower projects located at } \\
\text { non-federal dams). }\end{array}$ & & & $\begin{array}{l}\text { The Commission will not accept a } \\
\text { shorter or longer term than the } \\
40 \text {-year default policy if the term } \\
\text { length conflicts with coordinating } \\
\text { with other projects in a basin. } \\
\text { Settlement agreements that state } \\
\text { the settlement parties would not } \\
\text { oppose a certain term length or } \\
\text { would support a term length } \\
\text { within a range of years (e.g., 40- } \\
50 \text { years) are not considered "an } \\
\text { explicitly agreed upon license } \\
\text { term." }\end{array}$ \\
\hline
\end{tabular}

* FERC has not issued a final order on this licensing settlement agreement. 
Table 2. Types of Settlement Agreement Provisions That May Be Included As License Terms and Conditions or Off-license Provisions

\begin{tabular}{|l|c|c|}
\hline \multicolumn{1}{|c|}{$\begin{array}{c}\text { Type of Settlement } \\
\text { Agreement Provision }\end{array}$} & $\begin{array}{c}\text { License Term and } \\
\text { Condition }\end{array}$ & Off-License Provision \\
\hline Flow Level and Management & $\mathrm{X}$ & \\
\hline Species and Habitat Protection & $\mathrm{X}$ & \\
\hline Adaptive Management & $\mathrm{X}$ & $\mathrm{X}$ \\
\hline Water Quality & $\mathrm{X}$ & $\mathrm{X}$ \\
\hline Recreational Enhancements & $\mathrm{X}$ & $\mathrm{X}$ \\
\hline Conservation Easements & $\mathrm{X}$ & \\
\hline $\begin{array}{l}\text { Mitigation and Enhancement } \\
\text { Funds }\end{array}$ & $\mathrm{X}$ & $\mathrm{X}$ \\
\hline Dispute Resolution & $\mathrm{X}$ & $\mathrm{X}$ \\
\hline $\begin{array}{l}\text { Preservation of Historic } \\
\text { Properties }\end{array}$ & & $\mathrm{X}$ \\
\hline Cost Sharing & $\mathrm{X}$ & \\
\hline Cost Cap & $\mathrm{X}$ & \\
\hline Damages & & \\
\hline License Term Length & & \\
\hline
\end{tabular}

Settlement agreements are an accepted method to resolve disputes for any proceeding before the Commission (18 C.F.R. § 385.601[a]). Any hydropower project seeking a FERC authorization may enter into a settlement agreement to resolve a disputed issue. Further, the Commission encourages parties to enter into settlement agreements to resolve disputes (FERC 2006). This report summarized common settlement agreement provisions and the enforceability of these provisions by the Commission as license terms and conditions. The report provides a greater understanding of the bounds of the Commission's jurisdiction as well as highlights other mechanisms (i.e., off-license agreements) for enforcing provisions negotiated by settlement agreement parties. 


\section{References}

Federal Energy Regulatory Commission (FERC). 2004. "Handbook for Hydroelectric Project Licensing and 5 MW Exemptions from Licensing.”. https://www.ferc.gov/industries/hydropower/gen-info/handbooks/licensing handbook.pdf

2006. Settlements in Hydropower Licensing Proceedings under Part I of the Federal Power Act; Policy Statement on Hydropower Licensing Settlements (Docket No. PL06-5-000). https://www.ferc.gov/whats-new/comm-meet/092106/H-1.pdf.

2012. "A Guide to Understanding and Applying the Integrated Licensing Process Study Criteria.” Washington, D.C.https://www.ferc.gov/industries/hydropower/geninfo/guidelines/guide-study-criteria.pdf.

2015. "Division of Hydropower Administration and Compliance - Compliance Handbook (2015).” Washington, D.C. https://www.ferc.gov/industries/hydropower/geninfo/handbooks/compliance_handbook.pdf.

2017. “Policy Statement on Establishing License Terms for Hydroelectric Projects.” 161 FERC I 61,078 (Docket No. PL17-3-000). https://www.ferc.gov/whats-new/commmeet/2017/101917/H-1.pdf.

Roos-Collins, R., and J. Gantenbein. 2015. “Citizen Toolkit for Effective Participation in Hydropower Licensing.” Hydropower Reform Coalition. https://www.hydroreform.org/sites/default/files/201511\%20HRC\%20Citizens\%20Hydro\%20Guide_0.pdf.

Walker, Mary Ann. 1986. Settlement Practice at the FERC: Boom or Bane, 7 Energy L.J. 342, 34347. http://ebanet.org/sites/default/files/elj/Energy\%20Journals/Vol7_No2_1986_Settlementoom_or_Bane.pdf

Work Group on the Coordination of Federal Mandates. 2000. “Interagency Task Force Report on Improving the Studies Process in FERC Licensing.”

https://www.ferc.gov/industries/hydropower/indus-act/itf/studies_final.pdf.

\section{Federal Acts, Statutes, and Bills}

Clean Water Act of 1972, PL 92-500, 86 Stat. 47 (33 U.S.C. §§ 1251 - 1376 [October 18, 1972])

Federal Power Act of 1920, PL 66-281, 41 Stat. 1063 (16 U.S.C. §§ 791 - 828c [June 10, 1920])

National Environmental Policy Act of 1969, PL 91-190, 89 Stat. 493 (42 U.S.C. §§ 4321 - 4347 [January 1, 1970])

National Historic Preservation Act of 1966, PL 102-575, 80 Stat. 915 (16 U.S.C. $\S \S 470$ - 470x6 [October 15, 1966])

\section{Federal Regulations}

18 C.F.R. $\S \S 4.1$ - 4.401 (1947), Regulations under the Federal Power Act 
18 C.F.R. $\S \S 385.101$ - 385.2202 (1982), Federal Energy Regulatory Commission Rules of Practice and Procedure

40 C.F.R. §§ 1508.1 - 28 (1970), Council on Environmental Quality Rules and Regulations

Settlement Agreements and Offers of Settlement

Aquatic Settlement Agreement Wells Hydroelectric Project FERC License No. 2149 (2010)

Avista Corporation Cabinet Gorge and Noxon Rapids Hydroelectric Projects Settlement Agreement (1999)

Cabin Creek Pumped Storage Hydroelectric Project FERC Project No. 2351 Final Settlement Agreement (2013)

Ludington Pumped Storage Project Relicensing Settlement Agreement (2017)

Oswegatchie River Project Offer of Settlement (2011)

PPL Holtwood, LLC, Offer of Settlement and Explanatory Statement (2009)

Relicensing Settlement Agreement for the Upper American River Project and Chili Bar Hydroelectric (2007)

Relicensing Settlement Agreement for the Santee Cooper Project (2007)

Settlement Agreement Addressing Federal Power Act Section 4(e) Mandatory Conditions for Spokane River Project, FERC No. 2545, (2009)

Settlement Agreement for the Cushman Project (2009)

Settlement Agreement for the Henry M. Jackson Hydroelectric Project (2009)

Settlement Agreement for the Saccarappa Project (2016)

Yakin Hydroelectric Project Relicensing Settlement Agreement (2007)

York Haven Hydroelectric Project Offer of Settlement (2014)

Case Law, Dockets, and Orders

Alcoa Power Generating Inc., 110 FERC ๆ 61,056 (2005)

Alcoa Power Generating, Inc., 156 FERC $₫$ 62,210 (2016)

Anderson v. Liberty Lobby, Inc. 477 U.S. 242 (1986)

Avista Corporation, 93 FERC 61,116 (2000)

Avista Corporation, 90 FERC 9 61,167 (2000)

Avista Corp., 127 FERC ๆ 61,265 (2009) 
Boyce Hydro Power, LLC., 149 FERC 9 62, 027 (2014)

Centel Corp., Western Power Div., 27 FERC \ 63,071 (1984)

City of Tacoma, Washington 132 FERC \ 61,037 (2010)

Chugach Electric Association, 120 FERC \ 62,148 (2007)

Clifton Power Corp., FERC Docket No. P-4632-013 (1993)

Consolidated Gas Supply Corp., 27 FERC ๆ 61,426 (1984)

Consumers Power Company, 68 FERC ๆ 61,077 (1994)

Duke Energy Carolinas, LLC, 120 FERC \ 61,054 (2007)

Duke Energy Progress, Inc., 151 FERC | 62,004 (2015)

Duke Energy Progress, Inc., 153 FERC | 61,056 (2015)

El Paso Natural Gas Co., 24 FERC \ 63,008 (1983)

Energy Terminal Serv. Corp., 20 FERC ๆ 61,053 (1982)

Erie Boulevard Hydropower, L.P., 100 FERC ๆ 61,321 (2002)

Exelon Generation Company, LLC., 153 FERC \ 62,232 (2015)

Ketchikan Public Utilities, 126 FERC ๆ 62,205 (2009)

Michigan Wis. Pipe Line Co., 20 FERC \ 61,423 (1982)

Mobil Oil Corp., v. Fed. Power Comm’n, 417 U.S. 283 (1974)

New York Power Authority, 105 FERC ๆ 61,102 (2003)

New York Power Authority, 118 FERC \ 61, 206 (2007)

Niagara Mohawk Power Corp., 77 FERC \ 61,306 (1996)

Northern States Power Co., 111 FERC 9 62,212 (2005)

Oswegatchie River Hydroelectric Project, 141 FERC ๆ 62,125 (2012)

PacifiCorp, 104 FERC 9 62,059 (2003)

PacifiCorp, 105 FERC ๆ 62,207 (2003)

Pacific Gas and Electric Company, 69 FERC 61,070 (1994)

Panhandle E. Pipe Line Co., 29 FERC ๆ 61,281 (1984) 
Pennsylvania Gas \& Water Co. v. FPC, 463 F.2d 1242 (D.C. Cir. 1972)

Pepperell Hydro Company, LLC., 152 FERC \ 62,155 (2015)

Placid Oil Co. v. FPC, 483 F.2d 880 (5 $5^{\text {th }}$ Cir. 1973)

Portland General Electric Co., 117 FERC 9 61,112 (2006)

Portland General Electric Co., 133 FERC q 62,281 (2010)

Public Service Company of Colorado, 147 FERC \ 62,157 (2014)

Public Utility District No. 1 of Snohomish County, Washington, 136 FERC ๆ 62,188 (2011)

Public Utility District No. 1 of Douglas County, Washington, 141 FERC \ 62,104 (2012)

Sacramento Municipal Utility District, 148 FERC ๆ 62,070 (2014)

Symbiotics, 124 FERC ๆ 62,059 (2008)

Trunkline Gas Co., 22 FERC ๆ 63,114 at 65,398 (1983).

Trans-Alaska Pipeline Sys., 35 FERC | 61,425 (1983)

Union Electric Co., 118 FERC I 62,247 (2007)

Universal Camera Corp., v. NLRB, 340 U.S. 474 (1951)

Upper Peninsula Power Company, 104 FERC ๆ 62,135 (2003)

Virginia Electric Power Company, 111 FERC \ 61,241 (2005)

Wisconsin Public Service Corporation, 104 FERC ๆ 61,295 (2003)

York Haven Power Co., LLP, 153 FERC ๆ 62,233 (2014). 